\title{
Genetic basis and adaptive implications of temperature-dependent and temperature-independent effects of drought on chickpea phenology
}

Yongle Li ${ }^{1}$, Lachlan Lake ${ }^{1,2}$, Yashvir S. Chauhan ${ }^{3}$, Julian Taylor ${ }^{1}$, Victor O. Sadras ${ }^{1,2^{*}}$

${ }^{1}$ School of Agriculture, Food and Wine, The University of Adelaide

2 South Australian Research and Development Institute, Australia

${ }^{3}$ Department of Agriculture and Fisheries, Kingaroy, Australia

${ }^{*}$ corresponding author

YL: yongle.li@adelaide.edu.au

LL: lachlan.lacke@sa.gov.au

YSC: yash.chauhan@daf.qld.gov.au

JT: julian.taylor@adelaide.edu.au

VS: victor.sadras@sa.gov.au

Running title: drought effect of phenological development

Word count (Introduction to Acknowledgements, excluding Methods): 4644

7 Figures, 2 Tables 


\section{Highlight}

Predictive and genetic models that overlook drought effects on phenology can return biased predictions of adaptation to future climates. Here we study the genetic causes and adaptive consequences of hastened flowering under drought.

Abstract

Water deficit often hastens flowering of pulses partially because droughted plants are hotter. Separating temperature-independent and temperature-dependent effects of drought is important to understand, model and manipulate phenology genetically and agronomically.

We define a new trait, drought effect on phenology (DEP = difference in flowering time between irrigated and rainfed crops), and use Fst genome scan to probe for genomic regions under selection for this trait. Genomic regions overlapping for early- and late-sown crops would associate with temperature-independent effects and non-overlapping genomic regions would associate with temperature-dependent effects.

Time to flowering shortened with increasing water stress quantified with carbon isotope composition. Genomic regions on chromosomes 4, 5, 7 and 8 were under selection for DEP. An overlapping region for early and late sowing on chromosome 8 revealed a temperatureindependent effect with four candidate genes: BAM1, BAM2, HSL2 and ANT. The non-overlapping regions included six candidate genes: EMF1, EMF2, BRC1/TCP18, BZR1, NPGR1 and ERF1. Modelling to assess DEP adaptive value showed it reduces the likelihood of drought and heat stress at the expense of cold risk. Accounting for DEP would improve phenology models to predict adaptation to future climates and breeding against the combined risks of drought, heat, and cold stress.

Key words: carbon isotope, climate change, development, drought, flowering, genome, heat, phenotype, temperature, trade-off 


\section{Introduction}

Phenological shifts are the most conspicuous biological effects of global change, and the relative phenology of plants, herbivores and predators is central to the assemblage of trophic webs in natural and agricultural systems (Kankaanpää et al., 2020; Levine et al., 2002; Otegui et al., 2021; Parmesan, 2006; Richardson et al., 2013). Darwin (1859) observed “...very trifling changes, such as a little more or less water at some particular period of growth, will determine whether or not the plant sets a grain...". This notion of a critical developmental period for seed production is central to plant physiology and agriculture, as farmers pair genotype and sowing time to manipulate crop phenology against the risks of frost, heat, drought, herbivory, and disease (Berger et al., 2006; Berger et al., 2004; Hunt et al., 2019; Lake et al., 2021; Otegui et al., 2021).

Temperature and photoperiod modulate the transition from the vegetative to reproductive stage and are at the core of predictive models (Lake et al., 2021; Mauney, 1963; Patrick and Stoddard, 2010; Summerfield et al., 1985; Wallach et al., 2021; Zheng et al., 2013). Fragmented empirical evidence shows that water deficit often hastens flowering in temperate grain legumes including chickpea (Cicer arietinum, $2 n=2 x=16$ ), the focus of this study (Anbazhagan et al., 2015; Fang et al., 2011; Johansen et al., 1994; Lizarazo et al., 2017; Singh, 1991; Thomas et al., 2004). Genotypic variation in this response is largely unexplored. Likewise, the adaptive and agronomic value of hastened flowering in response to water deficit is unknown but is expected to vary with soil and climate driving the patterns of supply and demand of water (Jordan and Miller, 1980; Schwinning and Ehleringer, 2001; Tardieu, 2012). Few ad-hoc models capture the effect of drought on flowering time (Chauhan et al., 2019; Lizarazo et al., 2017; McMaster et al., 2011) but mainstream crop models commonly used in climate change predictions do not (Wallach et al., 2021). Overlooking the effect of plant water status on phenology can therefore bias predictions of crop adaptation to future climates.

In contrast to the hastening of flowering in droughted chickpea (Chauhan et al., 2019; Fang et al., 2011), water deficit delayed time to first flower in Tunisian populations of burr medic (Medicago polymorpha) from wet (664 mm annual rainfall) and intermediate ( $\left.345 \mathrm{~mm} \mathrm{yr}^{-1}\right)$ environments, with no effect on fast-developing populations from dry environments (173 mm yr-1) (Yousfi et al., 2015). The discrepancy between drought hastening or delaying development can be related to species, ecotype, and other factors such as the intensity of stress and interactions between water stress and temperature. For example, wheat (Triticum aestivum) phenological development responds non-linearly to plant water status, with mild water stress shortening and severe stress extending the time from floral initiation to anthesis (Angus and Moncur, 1977). In a factorial combining water regime and sowing time, 
water deficit hastened the flowering of mungbean (Vigna radiata) in early but not in late sowing, highlighting the interaction of water and temperature in modulating development (Thomas et al., 2004). Owing to the shift from latent heat to sensible heat, crop canopies are hotter under drought (Jones, 1992). Hence, hotter plant tissue may partially account for the effect of water deficit on phenology, but temperature-independent effects cannot be disregarded (McMaster et al., 2011). Separating temperature-dependent and temperature-independent effects of water deficit is important to understand, model and manipulate plant phenology genetically and agronomically.

Natural and agronomic selection may leave fingerprints in the genome, such as an extended genomic region where selection hitchhiking reduces diversity (Nielsen et al., 2005). The small genome of chickpea allows for whole-genome resequencing of contrasting genotypes to identify genomic regions under selection for agronomic traits (Li et al., 2017; Sadras et al., 2016). Fst genome scan, where Fst is the fixation index (Wright, 1950), uses a large number of molecular markers to scan regions with extreme genetic differentiation between diverging populations (Fumagalli et al., 2013; Holsinger and Weir, 2009). Fsт genome-scan is based on neutral theory, assuming that polymorphisms are selectively neutral and random genetic drift is the main driver of allele frequencies in populations without selection (Booker et al., 2020). This approach to detect selection signals in small samples has been insightfull in ecological and evolutionary settings (Barr et al., 2021; Van Bocxlaer, 2017), for crops including rice (Oryza sativa), wheat and chickpea (Jordan et al., 2015; Li et al., 2017; Sadras et al., 2016; Xu et al., 2012), and for crop pests such as the soybean aphid, Aphis glycines (Coates et al., 2020). The

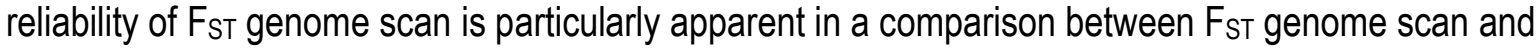
genome-wide association (GWAS), with both returning a common $100 \mathrm{~kb}$ region (AB4.1) on chromosome 4 associated with Ascochyta blight resistance in chickpea (Li et al., 2017).

Here we define a new trait, drought effect on phenology ( $D E P$ = difference in flowering time between irrigated and rainfed crops), to test three hypotheses in a study combining field experiments, FST genome scan, and modelling. First, time to flowering is shortened in proportion to plant water deficit, and this response is genotye-dependent. Second, the effect of drought on phenology involves genes associated with both temperature-independent and temperature-dependent components. Genomic regions under selction for $D E P$ that are common to early- and late-sown crops would support temperature-independent effects while non-common genomic regions would indicate temperaturedependent effects. Third, drought modulation of phenology drives a site-dependent reduction in drought and heat stress at the expense of cold stress; this hypothesis was tested with modelling in a northsouth transect with varying soils, rainfall and thermal regimes in eastern Australia. 


\section{Methods}

\section{Phenotyping phenology, carbon isotope composition and seed size in the field}

A field experiment was established on a calcic luvisol (Isbell, 1996) at Roseworthy, South Australia (340 $52^{\prime} \mathrm{S}, 138^{\circ} 69^{\prime} \mathrm{E}$ ) that combined factorially 20 genotypes (Table 1), two water regimes (dry, rainfed; wet, sprinkler irrigated), and two sowing times (early, early June; late, early-mid July). The experiment was repeated twice over successive seasons. Treatments were laid out in a split-split-plot design with three replicates, where sowing time was assigned to the main plot, water regime to the sub-plot, and genotypes randomised within each plot. Each plot comprised 6 rows, $0.24 \mathrm{~m}$ appart, 5-m long. Further details of the experiment are in Sadras et al. (2016).

To avoid bias associated with border effects, all measurements were made in the center rows (Rebetzke et al., 2014). We scored phenology weekly to establish the time to $50 \%$ of plants at beginning of flowering and calculated thermal time from sowing to flowering using a base temperature of $0{ }^{\circ} \mathrm{C}$ (Berger et al., 2006; Berger et al., 2004). To quantify crop water status, we measued carbon isotope composition $\left(\delta^{13} \mathrm{C}\right)$ at peak biomass, shortly after flowering. This trait integrates crop water status over the growing period until sampling time and is robust in relation to environmental conditions - radiation, wind speed, temperature, vapour pressure deficit (Condon et al., 2002), unlike traits such as stomatal conductance, leaf water potential or canopy temperature that vary with conditions at sampling time. Ten shoots per replicate were sampled and dried at $70^{\circ} \mathrm{C}$ for $48 \mathrm{~h}$; subsamples were ground and analysed for $\mathrm{C}$ isotope composition using a Europa 20-20 stable isotope ratio mass spectrometer with an ANCA-SL (Automated Nitrogen Carbon Analysis for Solids and Liquids) preparation system. In a batch of samples, after every eighth sample a test and a reference (Pee Dee Belemnite) were determined and used to correct for any drift or carryover in the instrument. Carbon isotope composition $\delta^{13} \mathrm{C}$ was calculated as (Condon et al., 2002):

$$
\delta^{13} \mathrm{C}(\% 0)=\left(\frac{\mathrm{R}_{p}}{\mathrm{R}_{r}}-1\right) \times 1000
$$

where $R$ is the ${ }^{13} \mathrm{C} /{ }^{2} \mathrm{C}$ ratio and subscripts indicate plant $(p)$ and reference $(r)$.

To probe for associations between phenology and seed weight, as expected from pleiotropic effects (Hovav et al., 2003; Kumar and Abbo, 2001), we measured average seed weight at maturity after drying and threshing 2- $\mathrm{m}^{2}$ plant samples. 
Statistical analysis of crop traits

Time from sowing to flowering, carbon isotope composition and seed weight were analysed with a linear mixed model (LMM) where the fixed component consisted of the crossed factor combinations of genotype, sowing time, water regime and season. This ensured the LMM fixed effects included main effects for each of the factors as well as the full complement of second, third and fourth order interactions. Additional sources of variation associated with aspects of the field design such as replicates, or non-linear trends across the rows or ranges of the experiment, were modelled using random effects. Due to the distinct sowing times within each season, and the potential for traits to vary significantly between water regimes, we partitioned the model residuals of the LMM to ensure a separate residual variance was specified for each combination of season by sowing time by water regime. From this complete model, Wald ANOVA tables were extracted for summary. To appropriately compare genotypes between water regimes, BLUEs for genotype by water regime by sowing time, and averaged over season, were predicted from the LMM.

Generalised broad-sense heritability was calculated for all traits using the method by Cullis et al. (2006). This involved re-fitting the LMM with the genotype factor as a random effect and leaving other terms unchanged in the LMM specification. Heritabilities are then considered to be averaged over water regimes, sowing times and seasons.

To explore associations between variables, we fitted least square regression (Model I) when error in $x$ was negligible in comparison to error in y and reduced maximum axis regression (RMA, Model II) to account for error in both $x$ and $y$ (Niklas, 1994). For both ANOVA and regressions, we present $p$ as continuous values, avoiding arbitrary $p$ thresholds for significance (Wasserstein et al., 2019).

Drought effect on phenology (DEP) was calculated in two ways, with difference- and residual-based approaches. First, we calculated DEP as the difference in flowering time between the dry and wet treatments. A reduced LMM was fitted using the above model, with the water regime treatment omitted. From this LMM, BLUEs for the genotypes within each sowing time were predicted. The second approach uses the BLUEs of flowering time by genotype, sowing time and water regime extracted from the full fitted LMM defined above. Within each sowing time, BLUEs of flowering time for the wet treatment were regressed against the BLUEs of flowering time for the dry treatment, and the residuals from the RMA regressions were taken as a proxy for DEP (Erena et al., 2021; McDonald et al., 2018). $D E P$ calculated as differences correlated closely with DEP calculated as residuals $(r=0.93$ for first sowing, $r=0.96$ for second sowing, $p<0.0001$ for both; Supplementary Figure 1). Hereafter, we report difference-based $D E P$ for clearer biological interpretation; for example, early sown Genesis Kalkee 
returned a difference-based $D E P=219{ }^{\circ} \mathrm{Cd}$, which means drought hastened flowering by $219{ }^{\circ} \mathrm{Cd}$ in relation to well-watered crops.

DNA sequencing and $\mathrm{F}_{\text {ST }}$ genome scan

DNA extraction and sequencing have been described previously (Sadras et al., 2016). Briefly, we extracted DNA of the 20 chickpea genotypes from young leaves using Qiagen DNeasy Plant Mini Kit. TruSeq libaries were constructed for each genotype with an insert size of 500 base pairs and sequenced using Illumina HiSeq 2000 platform. Pair-end reads (100 bp) were trimmed and mapped to the reference genome 2.6.3 (http://cicer.info) using SOAP2 (Li et al., 2009). To perform Fst genome scan, the BAM files of the top six and bottom six genotypes based on the adjusted entry means of DEP

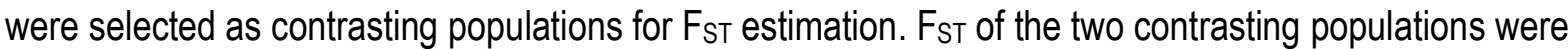
estimated using software ngsTools and ANGSD (Fumagalli et al., 2013; Fumagalli et al., 2014; Korneliussen et al., 2014). $F_{S T}$ is a measurement of genetic differentiation between populations, with larger Fst indicative of larger divergence between the populations. The whole genome was scanned for each $100 \mathrm{~kb}$ window (non-overlapping) to find regions with extreme $\mathrm{F}_{\mathrm{ST}}$ (compared with the adjacent regions) as an indicator of regions under selection. The assumption is that if a region is under selection, the pattern of genetic differentiation between populations may change, i.e. alleles may be fixed in a particular population. Genomic regions with the top $0.1 \%$ Fst were considered to be under selection (Sadras et al., 2016).

Modelling the adaptive value of drought effect on phenology

Current models reliably predict phenology but not yield of pulses particularly because algorithms are lacking that relate yield and extreme temperatures (Lake et al., 2021). Thus, to test our third hypothesis, we modelled the phenology of two contrasting genotypes - responsive vs. unresponsive to water deficit - to quantify the phenology-driven differences in water stress and temperature in the critical period from flowering to $200^{\circ} \mathrm{Cd}$ after flowering (Lake and Sadras, 2014). The expectation is reduced water stress and lower temperature during the critical period of the responsive genotype in relation to its unresponsive counterpart (Fig. 1a). We used APSIM (Classic version 7.10) to simulate flowering time and the daily water stress index, WSI. The WSI is the ratio between the potential water supply, which depends on the volume and wetness of soil explored by roots, and the water demand of the canopy, which is a function of radiation, ambient temperature and humidity (Chenu et al., 2011). 
The WSI ranges from 1 (no stress) to 0 (no growth) (Fig. 1a). APSIM is a widely used crop simulaton framework that has been extensively validated for multiple crops and environments in Australia and elsewhere (Holzworth et al., 2014; Keating et al., 2003). Tests of the model's ability to simulate phenology and WSI are particularly relevant for our study. Modelled chickpea flowering time as a function of temperature, daylength and soil water content correlated closely with measured flowering time in eastern Australia (Chauhan et al., 2019). The WSI has been extensively used for spatial characterisation of drought in many crop species and environments (Chenu, 2015). For chickpea in Australia, the modelled WSI is biologically and agronomically robust as it defines drought types that correlate with seed yield (Chauhan et al., 2017; Lake et al., 2016).

We modelled two "isolines", responsive and non-responsive to drought, using the same genetic parameters (Supplementary Table 1) except for phenological development of the responsive genotype for which developmental time was scaled with the algorighms developed and tested by Chauhan et al. (2019) to capture the drought effect on phenology. The two genotypes were compared in a factorial combining 11 locations in eastern Australia (Figure 1b), 65 years from 1957, five sowing times (at fortnigtly intervals from $14^{\text {th }}$ of May to $14^{\text {th }}$ of July) and two initial soil water contents (reset to field capacity or $50 \%$ field capacity on the 1 st of December of each preceding year). At sowing, a $20 \mathrm{~mm}$ irrigation was applied to ensure establishment. Climate data were sourced from Queensladn Goverment data base ${ }^{1}$. Phothethermal and rainfall regimes of these environments have been described in detail (Chauhan et al., 2017; Chauhan et al., 2008; Rodriguez and Sadras, 2007; Sadras and Rodriguez, 2007). Soil properties were obtained from the APSoil database (www.apsim.info). Out of the 7150 combinations in this factorial, 109 were failed crops as defined in Chauhan et al. (2017); the analysis thus focused on 7041 combinations. Using these data, the responsive and unresponsive genotypes were compared in two analyses. First, we calculated frequency distributions of flowering time, and WSI, maximum, minimum and mean temperature in the critical period. Second, for WSI and temepratures, one-to-one scatterplots were drawn against the null hypothesis of no difference between genotypes represented by the $y=x$ line; deviations from $y=x$ line were analysed with ANOVA to account for the effect of location, time of sowing and climate change. To assess the variation in the adaptive value of $D E P$ with climate change, we used the updated World Meteorological Organisation climatological standard (Hulme, 2020); data were partitioned in 'present-day' climate, from 1991, and 'historic' climate before 1991.

\footnotetext{
${ }^{1}$ https://www.longpaddock.qld.gov.au/silo/point-data/
} 


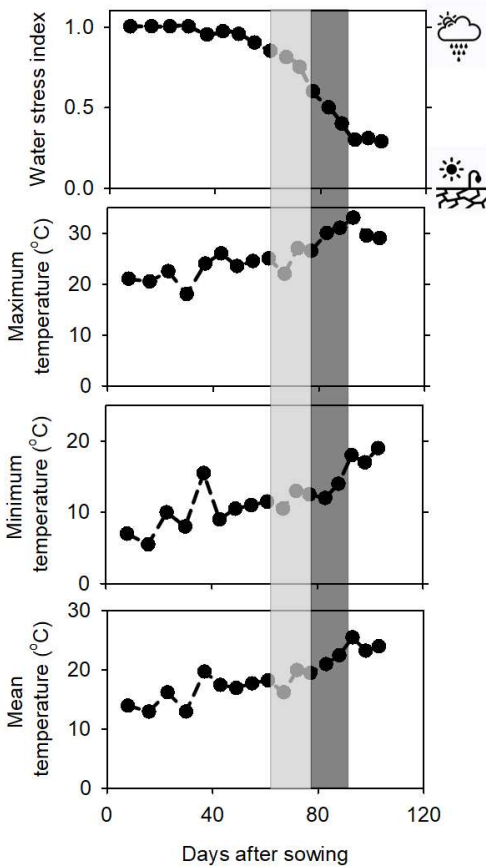

b

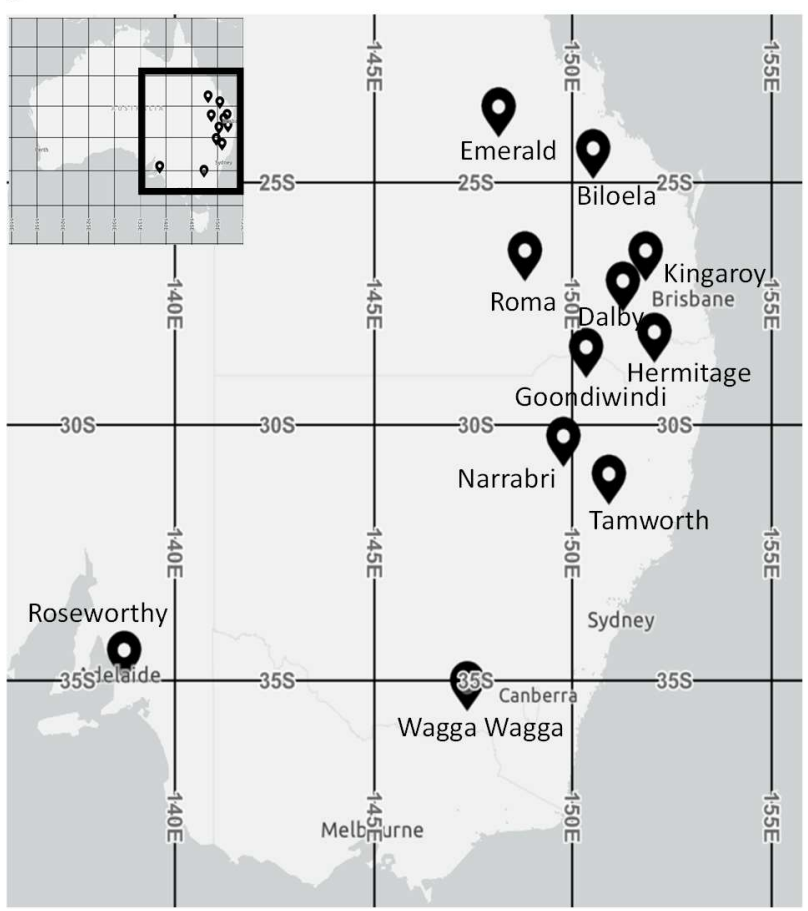

Figure 1. (a) Illustration of the dynamics of water stress index, maximum, minimum and mean temperature during the growing season of chickpea in relation to the critical period for a genotype responsive to water deficit (light grey) and an unresponsive genotype (dark grey). The water stress index ranges from 1 (no stress) to 0 (no growth). (b) Transect of locations in eastern Australia, from Emerald to Wagga Wagga, used to model the phenology, water stress index and temperature during the critical period; Roseworthy, the experimental site, was also included in the simulations.

Results

Photothermal and water regimes caused large variation in crop water status and phenology

Figure 2 summarises photothermal and water regimes. Solar radiation increased from 10.3-10.6 MJ m-2 for early sowing to $12.2-13.6 \mathrm{MJ} \mathrm{m}^{-2}$ with late sowing, maximum temperature from 16.8 to $18.6-19.9{ }^{\circ} \mathrm{C}$ and vapour pressure deficit from 0.70-0.73 kPa to 0.81-0.96 kPa (Fig. 1a).

Carbon isotope composition correlated with the ratio of water supply : demand (Fig. 2b). Carbon isotope composition indicated more severe water deficit in the dry than in the wet treatment and in late compared to early sowing (Fig. 2c, Supplementary Table 2). The difference in $\delta^{13} \mathrm{C}$ between wet and dry regimes was slightly smaller in late than in early-sown crops (Fig. 2c; Supplementary Table 2: water regime $x$ sowing time interaction, $p=0.06$ ). 
Daylength varied from 10.8 to $11.0 \mathrm{~h}$. (Fig. 2a). Detailed studies indicate this small variation in

a

\begin{tabular}{lllllllll}
\hline \multirow{2}{*}{ season } & \multirow{2}{*}{ sowing } & daylength & radiation & $T m a x$ & $T m i n$ & VPD & $\delta^{13} \mathrm{C}$ & flowering \\
\cline { 3 - 8 } & & $(\mathrm{h})$ & $\left(\mathrm{MJ} \mathrm{m}^{-2}\right)$ & $\left({ }^{\circ} \mathrm{C}\right)$ & $\left({ }^{\circ} \mathrm{C}\right)$ & $(\mathrm{kPa})$ & $(\% 0)$ & $\left({ }^{\circ} \mathrm{Cd}\right)$ \\
\hline \multirow{2}{*}{2} & early & 10.8 & 10.3 & 16.8 & 7.0 & 0.70 & $-27.28 \pm 0.082$ & $1190 \pm 8.7$ \\
& late & 10.9 & 12.2 & 19.9 & 7.3 & 0.81 & $-26.67 \pm 0.368$ & $1115 \pm 5.5$ \\
& early & 10.8 & 10.6 & 16.8 & 5.5 & 0.73 & $-25.96 \pm 0.127$ & $1058 \pm 7.7$ \\
& late & 11 & 13.6 & 18.6 & 4.9 & 0.96 & $-24.56 \pm 0.130$ & $877 \pm 4.7$ \\
\hline
\end{tabular}

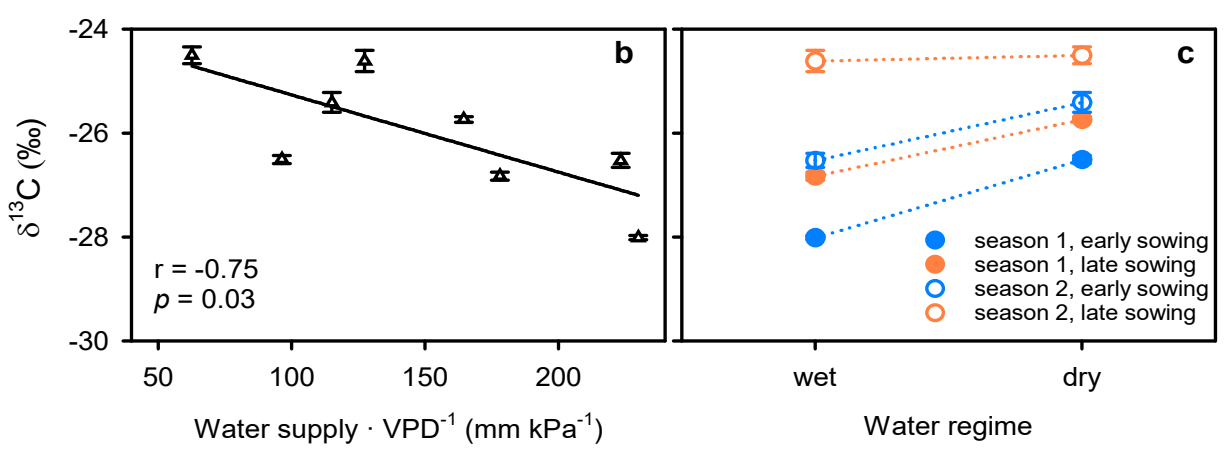

Figure 2. Photothermal and water regimes for chickpea crops associated with experimental sources of variation. (a) Daylength, solar radiation, maximum temperature (Tmax), minimum temperature (Tmin), vapour pressure deficit (VPD). Daylength is at sowing and the other weather variables are averages from sowing to average time of flowering of 20 genotypes. Carbon isotope composition $\left(\delta^{13} \mathrm{C}\right)$ and thermal time from sowing to flowering are averages ( \pm s.e.) across 20 genotypes. (b) Relationship between carbon isotope composition $\left(\delta^{13} \mathrm{C}\right)$ and water supply : vapour pressure deficit ratio. Water supply and VPD are average from sowing to average time of flowering of 20 genotypes; owing to the lack of reliable measurement of plant available water at sowing, water supply was calculated as the sum of rainfall and irrigation. The line is the least square regression. (c) Variation in $\delta^{13} \mathrm{C}$ with water regime, season and sowing date. In b and $\mathrm{c}, \delta^{13} \mathrm{C}$ is the environmental mean, calculated as the average of 20 genotypes. In b and c, error bars are two standard errors of the mean and are not shown when smaller than symbol.

Hypothesis 1: time to flowering is shortened in proportion to plant water deficit and this effect is genotype-dependent

Broad-sense heritability of thermal time to flowering was 0.98 ; it varied with genotype, water regime and sowing time from $885^{\circ} \mathrm{Cd}$ or $69 \mathrm{~d}$ for late-sown Sonali in the dry treatment to $1362{ }^{\circ} \mathrm{Cd}$ or $109 \mathrm{~d}$ for early-sown Genesis Kalkee in the wet treatment (Table 1, Supplementary Table 2). 
Table 1. Thermal time $\left({ }^{\circ} \mathrm{Cd}\right)$ from sowing to flowering in 20 chickpea genotypes grown under two water regimes averaged for two seasons.

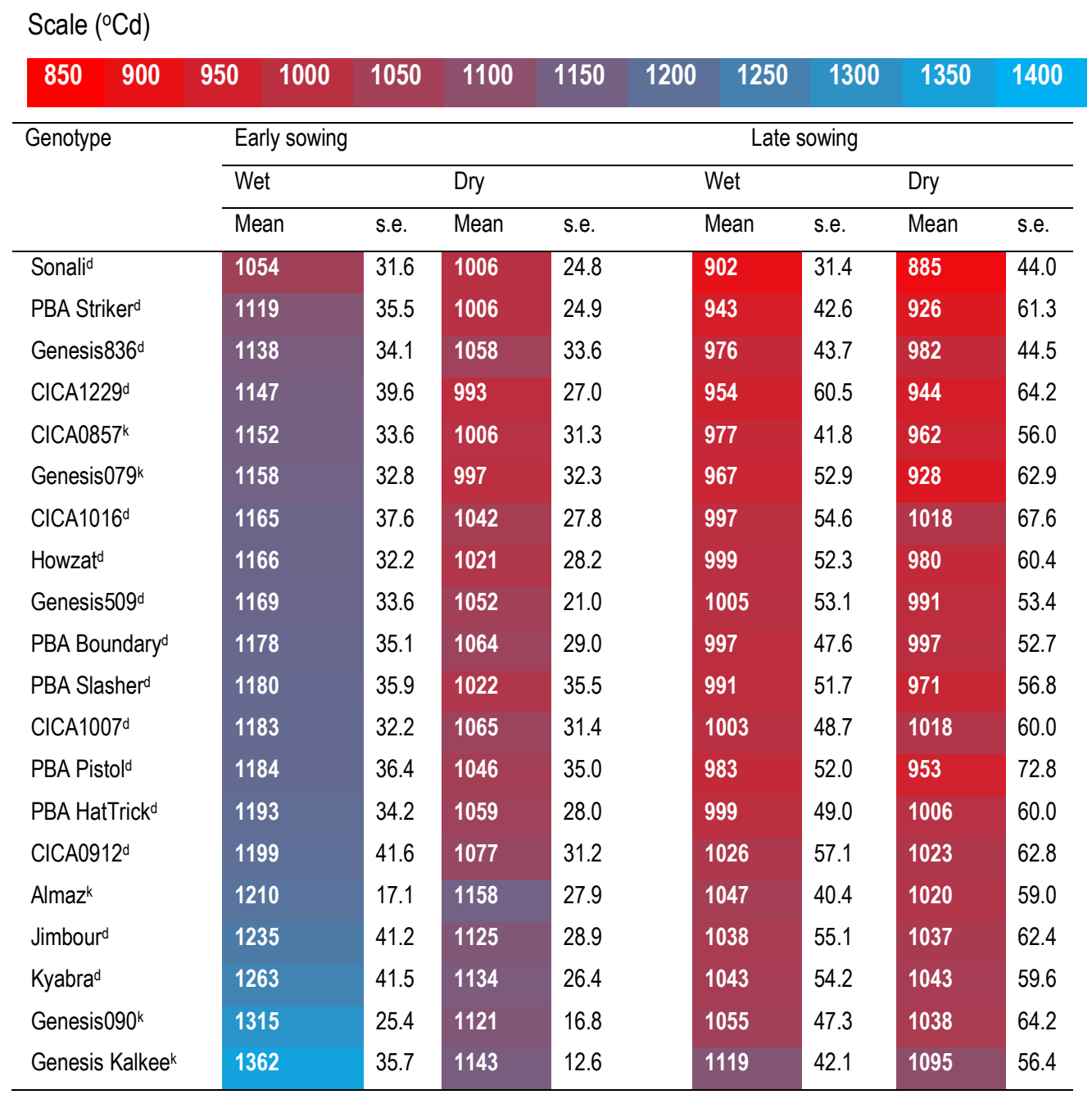

246 Broad-sense heritability of $\delta^{13} \mathrm{C}$ was 0.78 and thermal time from sowing to flowering correlated strongly

with $\delta^{13} \mathrm{C}$ (Figure 3a). A non-linear model improved slightly the correlation between thermal to flowering and $\delta^{13} \mathrm{C}$, with $\mathrm{p}=0.003$ for the quadratic term (dashed line in Fig. 3a).

Broad-sense heritability of seed weight was 0.99 . As expected from pleiotropic effects, thermal time to flowering correlated with seed weight; the slope of the RMA regression, $0.63^{\circ} \mathrm{Cd} \mathrm{mg}{ }^{-1}$, could be useful for modelling (Fig. 3b).

Broad-sense heritability of drought effect on phenology was 0.61 . This trait varied with genotype, sowing time, and with the interaction between genotype and sowing time: 4.6-fold in early-sown crops, from $47^{\circ} \mathrm{Cd}$ in Sonali to $218{ }^{\circ} \mathrm{Cd}$ in Genesis Kalkee, and smaller (1.9-fold) variation in their late-sown counterparts (Fig. 4, Supplementary Table 3). 

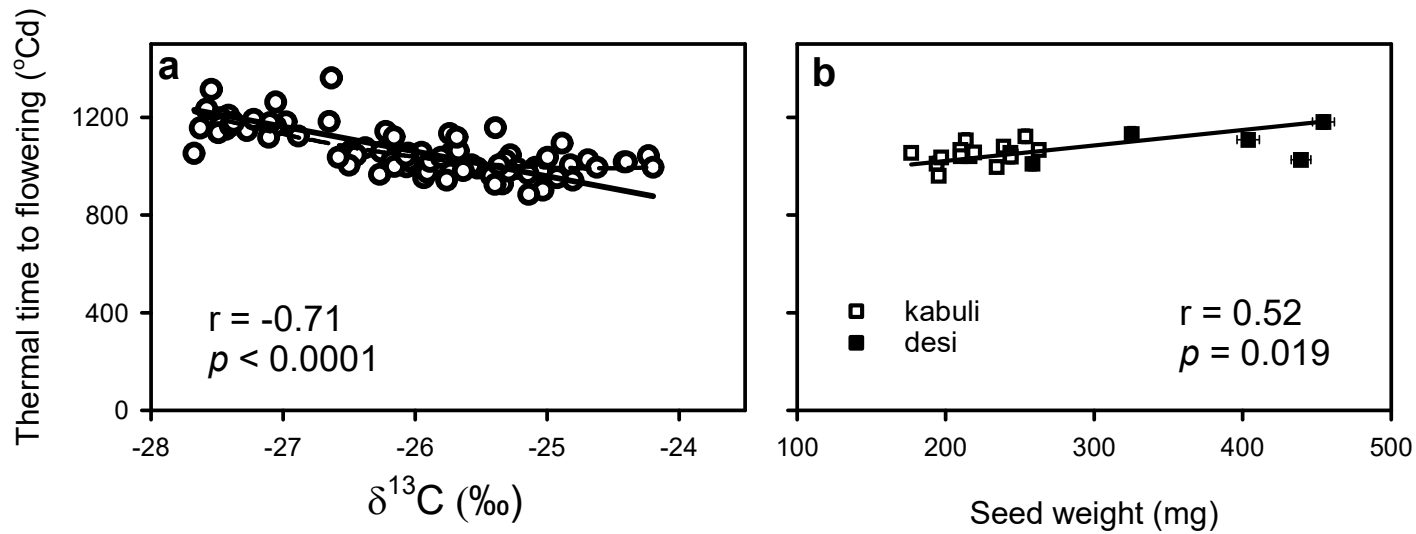

Figure 3. (a) Association between thermal time from sowing to $50 \%$ flowering and carbon isotope composition $\delta^{13} \mathrm{C}$ in 20 chickpea genotypes grown under two water regimes and two sowing dates across two seasons. (b) Association between thermal time from sowing to $50 \%$ flowering and average seed weight for 20 genotypes averaged across sources of variation. In $b$, error bars are two standard errors and are not shown when smaller than symbol. In $a, b$, the solid lines are reduced maximum axis regression (RMA, Model II) to account for error in both $x$ and $y$ (Niklas, 1994). The dashed line in (a) is a quadratic model with slightly higher $r^{2}$ than the linear model (0.54 vs 0.49$)$.

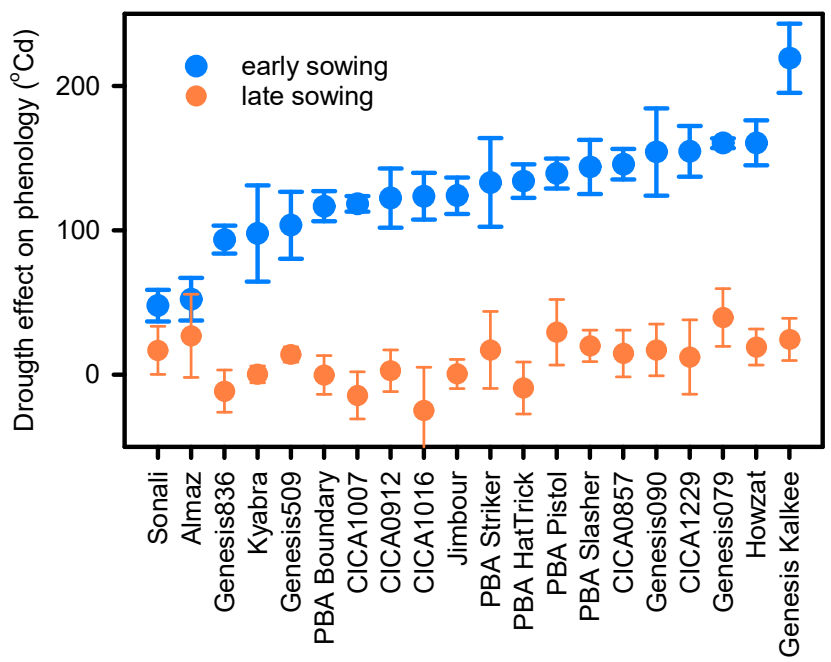

Figure 4. Genotype-dependent variation in drought effect on phenology, defined as the difference in thermal time from sowing to flowering between dry and wet treatments. Data are averaged across two experimental seasons and error bars are two standard errors. 


\section{Hypothesis 2: Fsт genome scan revealed genes associated with temperature-independent and} temperature-dependent effects of drought on phenology

Figure 5 shows the FST genome scan to probe for the effects of drought on phenology, Supplementary Table 4 lists the genes located within $250 \mathrm{~kb}$ of the genomic regions under selection (top $0.1 \% \mathrm{FsT}_{\mathrm{ST}}$ ) for this trait, and Table 2 summarises selected candidate genes. Genomic regions on chromosomes 4, 5, 7 and 8 were under selection for DEP. For early sowing, Fst scan identified four genomic regions on chromosomes 5 and 8 that were under selection. For late sowing, four regions on chromosomes 4, 5, 6 and 8 were found under selection. Regions on chromosome 8 common to the two sowing times, which are only $\sim 100 \mathrm{~kb}$ apart with high linkage disequilibrium among SNPs $\left(r^{2}=0.42\right)$, indicate a common set of genes associated with drought effect on phenology independent of temperature.

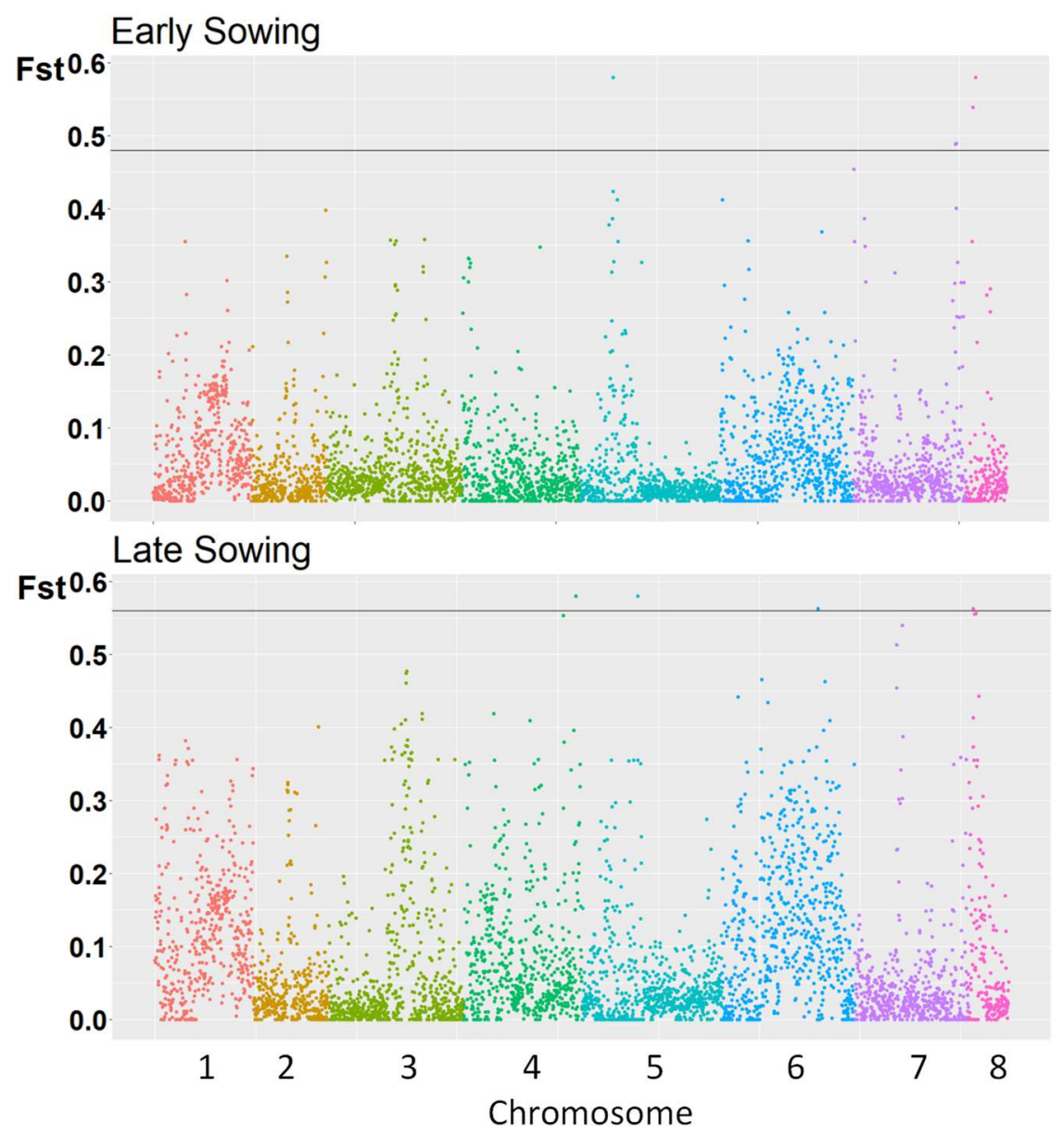

Figure 5 Fst genome scan for drought effect on phenology in early and late sown chickpea. The x-axis corresponds to the eight chickpea chromosomes and each dot represents a FST estimated using SNPs from a window of $100 \mathrm{~kb}$ region. The horizontal line is the top $0.1 \%$ threshold. Dots above the threshold are genomic regions considered to be under selection for drought effect on phenology. 
bioRxiv preprint doi: https://doi org/101101/2022 $0126.477940 ;$ this version posted January 28,2022 . The copyright holder for this preprint (which was not certified by peer review) is the author/funder, who has granted bioRxiv a license to display the preprint in perpetuity. It is made available under aCC-BY-NC 4.0 International license.

\begin{tabular}{|c|c|c|c|c|c|}
\hline Sowing time & $\begin{array}{l}\text { Gene name } \\
\text { (symbol) }\end{array}$ & $\begin{array}{l}\text { Physical } \\
\text { position (ref. } \\
\text { Kabuli } \\
\text { v2.6.3) }\end{array}$ & $\begin{array}{l}\text { Biological } \\
\text { function }\end{array}$ & $\begin{array}{l}\text { Gene } \\
\text { ID/UniRef90 }\end{array}$ & Reference \\
\hline early & $\begin{array}{l}\text { Embryonic flower } 1 \\
\text { (EMF1) }\end{array}$ & $\begin{array}{l}\text { Ca5:16,086,9 } \\
77-16,091,507\end{array}$ & $\begin{array}{l}\text { represses floral } \\
\text { development }\end{array}$ & $\begin{array}{l}\text { UPI00032A66 } \\
9 A\end{array}$ & $\begin{array}{l}\text { (Aubert et al., } \\
\text { 2001; Calonje et } \\
\text { al., 2008) }\end{array}$ \\
\hline early & $\begin{array}{l}\text { BRANCHED } 1 \\
\text { (BRC1/TCP18) }\end{array}$ & $\begin{array}{l}\text { Ca7:5125960 } \\
1-51260766\end{array}$ & $\begin{array}{l}\text { represses the } \\
\text { floral transition }\end{array}$ & $\begin{array}{l}\text { UPI00032A8F } \\
\text { B8 }\end{array}$ & $\begin{array}{l}\text { (Niwa et al., } \\
\text { 2013) }\end{array}$ \\
\hline early & $\begin{array}{l}\text { BRASSINAZOLE- } \\
\text { RESISTANT } 1 \\
\text { (BZR1) }\end{array}$ & $\begin{array}{l}\text { Ca8:4708153- } \\
4710162\end{array}$ & $\begin{array}{l}\text { regulates ovule } \\
\text { and seed } \\
\text { development }\end{array}$ & G7KC60 & $\begin{array}{l}\text { (Huang et al., } \\
\text { 2013) }\end{array}$ \\
\hline early and late & $\begin{array}{l}\text { Barely any } \\
\text { meristem } 1 \text { (BAM1) }\end{array}$ & $\begin{array}{l}\text { Ca8:3107330- } \\
3111514\end{array}$ & $\begin{array}{l}\text { ovule \& pollen } \\
\text { development }\end{array}$ & $\begin{array}{l}\text { UPI00032AB8 } \\
1 \mathrm{E}\end{array}$ & $\begin{array}{l}\text { (DeYoung et al., } \\
\text { 2006) }\end{array}$ \\
\hline early and late & $\begin{array}{l}\text { Barely any } \\
\text { meristem } 2 \text { (BAM2) }\end{array}$ & $\begin{array}{l}\text { Ca8:3118884- } \\
3119552\end{array}$ & $\begin{array}{l}\text { ovule \&pollen } \\
\text { development }\end{array}$ & $\mathrm{NA}$ & $\begin{array}{l}\text { (DeYoung and } \\
\text { Innes, 2006) }\end{array}$ \\
\hline early and late & $\begin{array}{l}\text { HAESA-LIKE2 } \\
\text { (HSL2) }\end{array}$ & $\begin{array}{l}\text { Ca8:3131445- } \\
3134732\end{array}$ & $\begin{array}{l}\text { activates floral } \\
\text { organ abscission }\end{array}$ & $\begin{array}{l}\text { UPI00032ABF } \\
95\end{array}$ & $\begin{array}{l}\text { (Gubert and } \\
\text { Liljegren, 2014) }\end{array}$ \\
\hline early and late & $\begin{array}{l}\text { AINTEGUMENTA } \\
(A N T)\end{array}$ & $\begin{array}{l}\text { Ca8:3252643- } \\
3255893\end{array}$ & $\begin{array}{l}\text { increases growth } \\
\text { of floral organs }\end{array}$ & $\begin{array}{l}\text { UPI00032A56 } \\
\text { D4 }\end{array}$ & $\begin{array}{l}\text { (Elliott et al., } \\
\text { 1996; Krizek, } \\
\text { 2009) }\end{array}$ \\
\hline late & $\begin{array}{l}\text { No Pollen } \\
\text { Germination1 } \\
\text { Related (NPGR1) }\end{array}$ & $\begin{array}{l}\text { Ca4:5577183 } \\
5-55775580\end{array}$ & $\begin{array}{l}\text { promotes pollen } \\
\text { germination }\end{array}$ & $\begin{array}{l}\text { UPI00032A89 } \\
\text { E3 }\end{array}$ & $\begin{array}{l}\text { (Golovkin and } \\
\text { Reddy, 2003) }\end{array}$ \\
\hline late & $\begin{array}{l}\text { EMBRYONIC } \\
\text { FLOWER } 2 \text { (EMF2) }\end{array}$ & $\begin{array}{l}\text { Ca8:2508573- } \\
2516476\end{array}$ & $\begin{array}{l}\text { represses floral } \\
\text { development }\end{array}$ & $\begin{array}{l}\text { UPI00032AC } \\
\text { D72 }\end{array}$ & $\begin{array}{l}\text { (Yoshida et al., } \\
\text { 2001) }\end{array}$ \\
\hline late & $\begin{array}{l}\text { ethylene-responsive } \\
\text { transcription factors } \\
1 \text { (ERF1) }\end{array}$ & $\begin{array}{l}\text { Ca8:2490746- } \\
2491517\end{array}$ & $\begin{array}{l}\text { delays } \\
\text { flowering/floral } \\
\text { initiation }\end{array}$ & $\begin{array}{l}\text { UPI00032A51 } \\
19\end{array}$ & $\begin{array}{l}\text { (Chen et al., } \\
\text { 2021) }\end{array}$ \\
\hline
\end{tabular}

Table 2 Selected candidate genes idenfitied to be under selection for drought effect on phenology. Three groups are considered: genes only identified in early- or late-sown crops (blue background), and those common to earlyand late-sown crops.

Hypothesis 3. Water deficit modulation of phenology drives a site-dependent reduction in water stress and heat stress at the expense of cold risk in eastern Australia

Figure 6 shows histograms of modelled flowering time, water stress index and temperature in the critical period, and Supplementary Table 5 summarises the associated statistics. On average, time to flowering was $16 \mathrm{~d}$ or $227^{\circ} \mathrm{Cd}$ shorter in the responsive genotype compared to its unresponsive counterpart.

The frequency distribution of water stress index was J-shaped, with negative skewness and positive kurtosis. The number of cases with WSI = 1 (no stress) decreased from 5384 out of $7041(76 \%)$ in the responsive genotype to 3186 (45\%) for the unresponsive one.

Owing to the hastened phenology with water deficit, the responsive genotype averaged $1.9^{\circ} \mathrm{C}$ lower maximum temperature, $1.6^{\circ} \mathrm{C}$ lower minimum temperature and $1.7^{\circ} \mathrm{C}$ lower mean temperature in the 

critical period than the unresponsive genotype. Maximum temperature over $30^{\circ} \mathrm{C}$ (Devasirvatham et al., 2012) and mean temperature below $15^{\circ} \mathrm{C}$ (Berger et al., 2012) in the critical period compromise chickpea reproduction. Maximum temperature over $30^{\circ} \mathrm{C}$ was reduced from 183 cases in the unresponsive genotype to no cases for its responsive counterpart. Mean temperature below $15{ }^{\circ} \mathrm{C}$ increased from 2148 cases (31\%) in the unresponsive genotype to 3073 cases (44\%) for its responsive counterpart.
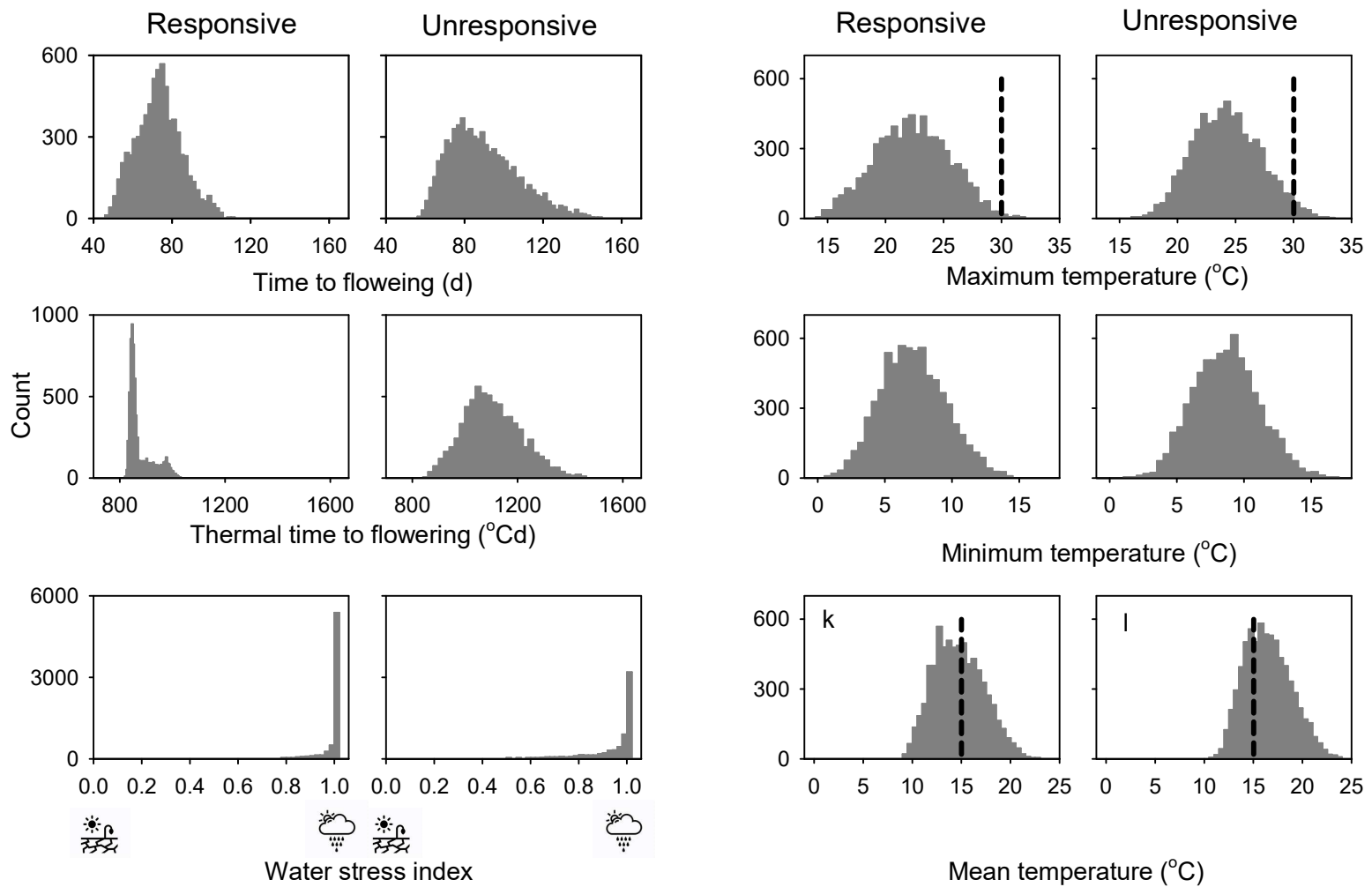

Figure 6. Frequency distribution of time from sowing to flowering and thermal time from sowing to flowering, and water stress index, maximum, minimum and mean temperature in the critical period of chickpea for a genotype phenologically responsive to water deficit and an unresponsive genotype. Modelled data from the combination of 11 locations, 65 seasons, two levels of initial soil water and five sowing dates ( $n=7041$, resulting from 7150 combinations minus 109 failed crops). The dashed lines are thresholds for reproductive disruption: above $30^{\circ} \mathrm{C}$ for maximum temperature (Devasirvatham et al., 2012) and below 15 ${ }^{\circ} \mathrm{C}$ for mean temperature (Berger et al., 2012).

295

One-to-one comparisons help visualise the difference in water stress and temperature in the critical period between responsive and unresponsive genotypes (Fig. 7aei). Data close to the $y=x$ line would indicate no difference between genotypes. The water stress index was on or below the $y=x$ line in Fig. $7 \mathrm{a}$, highlighting the consistent alleviation of drought associated with the hastening of flowering in the genotype responsive to water deficit. The one-to-one comparison showed most data were above the $y$ $=x$ line for both maximum and minimum temperature, reflecting the cooler critical period associated with earlier flowering in the responsive genotype (Fig. 7e, i). However, there were departures from this 

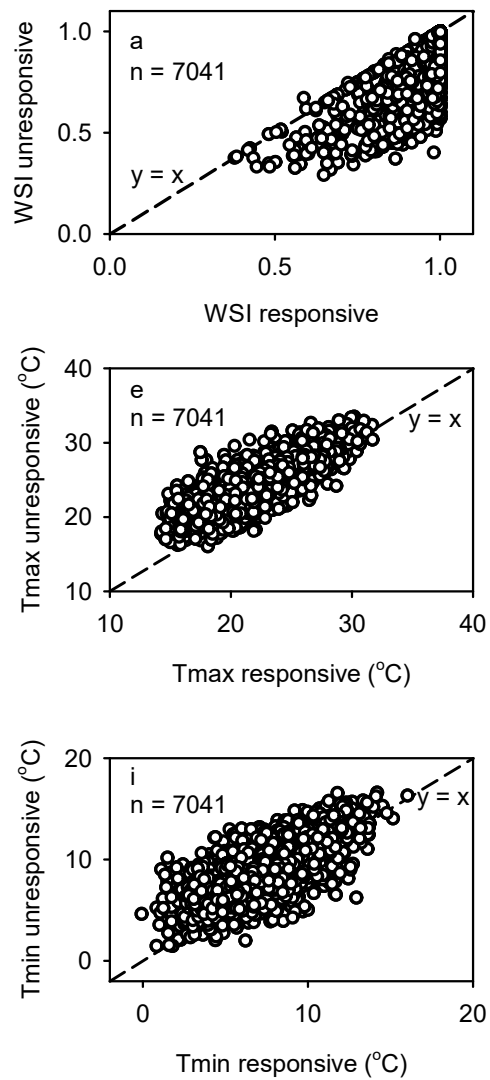

trend as the responsive genotype experienced lower maximum temperature than the unresponsive genotype in 839 cases $(12 \%)$ and lower minimum temperature in 1170 cases $(17 \%)$.
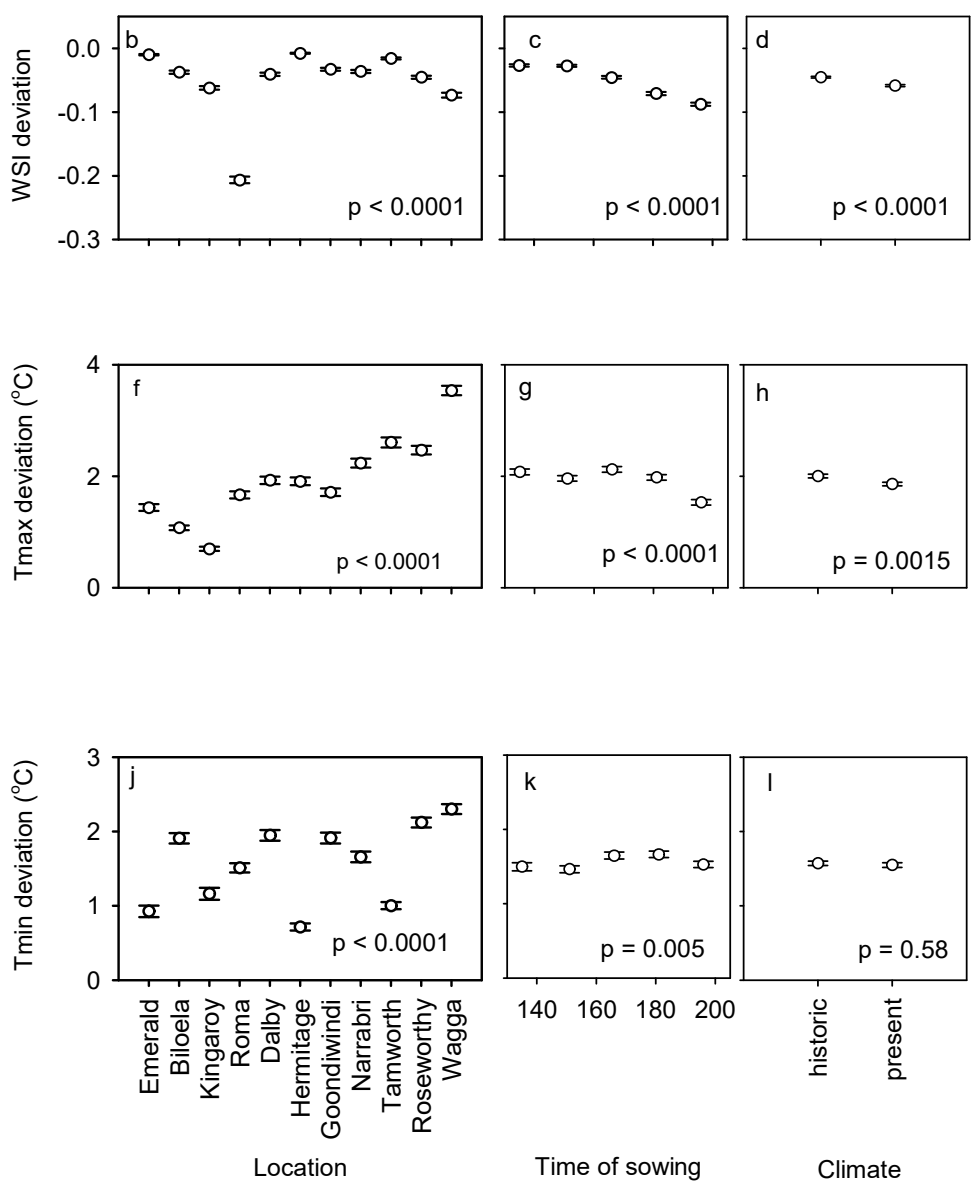

Figure 7. One-to-one comparisons of (a) water stress index, (e) maximum temperature and (i) minimum temperature during the critical period of chickpea between unresponsive and responsive genotypes. Modelled data are from the combination of 11 locations, 65 seasons, two levels of initial soil water and five sowing dates $(n=$ 7041 , resulting from 7150 combinations minus 109 failed crops). The dashed line, $y=x$, represents the null hypothesis of no difference between genotypes. Average deviation of WSI from the $y=x$ line for (f) 11 locations, (c) five sowing times, and (d) historic and present climate. Average deviation of maximum temperature from the $y=$ $x$ line for (f) 11 locations, (g) five sowing times, and $(\mathrm{h})$ historic and present climate. Average deviation of minimum temperature from the $y=x$ line for (j) 11 locations, (k) five sowing times, and (l) historic and present climate. In bcd, fgh, jkl error bars are two standard errors and p from ANOVA. In bjf, locations are from north to south.

Deviations of the water stress index from the $y=x$ line varied with location, sowing time, and climate (Fig. $7 b c d$ ). Owing to the large data set, all three sources of variation returned $p<0.0001$, but the size of the effect ranked location $>$ sowing time $>$ climate (Fig. $7 \mathrm{bcd}$ ). The deviation was small in Emerald and Hermitage, and largest in Roma due to shallow soil $(0.7 \mathrm{~m})$ in this location. The deviations of water 
stress index from the $y=x$ line were larger in more stressful locations (Supplementary Figure 2), indicating a larger adaptive value of drought effect on phenology under more severe drought. Deviations in water stress index from the $y=x$ line declined from early to late sown crops (Fig. 7c) and were slightly larger for present compared to historic climate (Fig. 7d). For maximum (Fig. $7 \mathrm{fgh}$ ) and minimum temperature (Fig. 7jkl), deviations were larger for location than for time of sowing, with little or no variation with climate. The deviations for maximum temperature increased southwards (Fig. 7f) with no latitudinal trend for minimum temperature (Fig. 7j).

\section{Discussion}

In this study we define a new trait, drought effect on phenology, and demonstrate it is genotypedependent, with a broad-sense heritability of 0.61 for our combination of genotypes and environments (Fig. 4); it comprises temperature-dependent and temperature-independent components associated with distinct genomic regions (Fig. 5) that map to genes related to floral development, hormone signalling and abiotic stress signalling (Supplementary Table 4, Table 2), and is involved in a sitedependent adaptive trade-off whereby a hastening of reproductive development with water deficit reduces the risk of drought and heat stress during the critical period of yield formation at the expense of cold risk (Fig. 6, 7, Supplementary Fig. 2).

Candidate genes involved in the development of reproductive organs, hormone signalling and abiotic stress signalling were under selection for drought effect on phenology

FsT genome scan reliably identifies genomic regions associated with ecologically and agronomically important traits in small populations (Barr et al., 2021; Jordan et al., 2015; Li et al., 2017; Sadras et al., 2016; Van Bocxlaer, 2017; Xu et al., 2012). Genomic regions associated with DEP in early- or latesown crops, but not in both, were assumed to reflect the temperature-dependent component of the trait. There were 232 predicted genes located within $250 \mathrm{~kb}$ of the peaks for $D E P$ in early sowing, including genes involved in floral development, hormone signalling and abiotic stress signalling. For example, the embryonic flower 1 (EMF1) gene is a repressor of the floral meristem determinacy gene AGAMOUS during vegetative development in Arabidopsis thaliana via polycomb group (PcG)-mediated gene silencing (Aubert et al., 2001; Calonje et al., 2008). Another gene, BRANCHED1 (BRC1/TCP18), interacts with the florigen proteins FLOWERING LOCUS T (FT) to repress the floral transition of the axillary meristems in $A$. thaliana (Niwa et al., 2013). There were 240 predicted genes located within $250 \mathrm{~kb}$ of the $\mathrm{F}_{\text {ST }}$ peaks for DEP in late sowing (Supplementary Table 4). Some of them are invovled in 
floral development and abiotic stress signalling. Among them, EMBRYONIC FLOWER 2 (EMF2) has been revealed to encode a novel zinc finger protein that repress reproductive development by changing flowering time and shoot morphogenesis (Yoshida et al., 2001). Further, EMF2 protein was recruited to interact with several key regulatory genes ( $A B / 3, L O V 1$, and $F L C)$ involved in FLC-mediated flowering pathway, seed development, and cold signalling (Kim et al., 2010). We also identified the NPGR1 gene (No Pollen Germination1 Related), one of the three closely related calmodulin-binding proteins, which is essential for pollen germination (Golovkin and Reddy, 2003). Additionally, there are four ethyleneresponsive transcription factors: ERF110, ERF1A, ERF034, and WIN1. They all contain a DNA binding domain (AP2 domain) that could bind to genes that respond to abiotic and biotic stresses (Muller and Munne-Bosch, 2015). Some members of the ERF family regulate floral development through environmental stimuli or hormones (Krizek, 2009; Licausi et al., 2013). One key, well-characterised member, ERF1, is involved in ethylene signalling (Muller and Munne-Bosch, 2015), and drought and heat stress (Cheng et al., 2013). Recently, ERF1 was shown to associate with a delay in Arabidopsis flowering/floral initiation through direct inhibition of the expression of the key floral integrator FT (Chen et al., 2021). Of interest, some ERFs play a role in plant-pathogen relations providing further biological links between phenological development and disease resistance. For example, ERF5 and ERF6 are positive regulators of JA-mediated defence and their constitutive expression increased resistance of $A$. thaliana to the fungal necrotroph Botrytis cinerea (Moffat et al., 2012). Magnaporthe oryzae, the causal agent of rice blast disease, strongly induced RiceOsERF922, encoding an APETELA2/ethylene response factor (AP2/ERF) (Liu et al., 2012). The phenotypic and genetic links between phenological development and disease tolerance have been and remain critical for chickpea adaptation, as discussed in the next section.

FST peaks on chromosome 8 common to early and late sowing are nearby ( $\sim 00 \mathrm{~kb})$ with high linkage disequilibrium. The $250 \mathrm{~kb}$ regions surrounding the two peaks overlapped and contain genes associated with a temperature-independent drought effect on phenology. In this region, a cluster of four genes was identified that relates to floral and reproductive development of Arabidopsis. One of them is the HAESA-LIKE2 (HSL2) receptor-like kinase that activates floral organ abscission, a cell-separation process that allows plants to develop their organ shape in response to developmental cues and environmental stress (Gubert and Liljegren, 2014). The other two genes, BAM1 and BAM2, play important roles in ovule and pollen formation (DeYoung and Innes, 2006; Hord et al., 2006). Their functions appear to be overlapping and opposite to that of CLAVATA 1 , a key protein kinase in regulating the development of shoot and flower meristems. The BAM2 gene in the chickpea reference genome Kabuli v2.6.3 is incomplete, with only $200 \mathrm{bp}$ of the total $3000 \mathrm{bp}$ length. It is unclear whether 
this is an assembly error or a loss of function deletion that often arises from gene duplication. We also identified the AP2 transcription factor AINTEGUMENTA (ANT) gene, which is involved in regulating ovule and female gametophyte development and promotes early floral primordia growth through stimulating cell growth in floral organs (Elliott et al., 1996; Krizek, 2009; Krizek et al., 2021). Interestingly, the upstream regulator of ANT, BRASSINAZOLE-RESISTANT 1 (BZR1), locates in another $F_{S T}$ peak for $D E P$ in early sowing (1.5Mb away from each other). The BZR1 mutant can increase the number of ovules and seeds in Arabidopsis through the brassinosteroid signalling pathway (Huang et al., 2013). Also, BZR1 was able to up-regulate the expression of ANT by binding to its promoter sequence and is thus involved in plant reproductive development (Huang et al., 2013).

We did not find any genomic region under selection for DEP overlapping the typical genes reported for flowering time in response to photoperiod and temperature in chickpea (Gaur et al., 2015; Gursky et al., 2018). The corollary of this putative genetic independence is that phenotypes combining slow or fast development, as mediated by photoperiod and temperature, and small or large responsiveness to drought can be tailored to target environments.

\section{Drought effect on phenology may be adaptive and involves trade-offs}

To interpret the assumed adaptive value of drought effect on phenology, we first outline the interplay between phenology, climate, and Ascochyta blight, as drivers of evolution, and early and contemporary cultivation of chickpea (Abbo et al., 2002; Abbo et al., 2003; Abbo et al., 2008; Daba et al., 2016a; Kumar and Abbo, 2001; Li et al., 2017; Lichtenzveig et al., 2006). In the Near East's archaeological record, chickpea first appears with the "large-seeded legumes" about 13,000 Cal BP, followed by a gap of about 3,000 years, and its re-appearance in the Bronze age. The gap has been attributed to Ascochyta blight, which devastated autumn-sown crops, and the re-appearance of the crop associated with the shift from autumn to spring sowing to avoid disease (Abbo et al., 2003). The selective pressure in favour of a spring-summer phenotype has reduced or eliminated vernalization requirements in cultivated chickpea in comparison to both wild Cicer spp and the companion foundational crops in the Levante (Abbo et al., 2002; Abbo et al., 2003; Berger et al., 2005; Kumar and Abbo, 2001; Pinhasi VanOss et al., 2016). In western Canada where short growing season and Ascochyta blight challenge contemporary chickpea production, a collection of recombinant inbred lines showed negative correlations between days to flowering and Ascochyta blight resistance, and revealed clusters of QTL for days to flowering and blight resistance that partially overlap on chromosomes $3(8.6-23.11 \mathrm{cM})$ and 8 (53.88-62.33 cM) (Daba et al., 2016a). In Australia where the current crop is autumn-sown, the legacy of selection for summer growth habit is apparent in two traits: slow canopy growth under low 
bioRxiv preprint doi: https://doi.org/10.1101/2022.01.26.477940; this version posted January 28, 2022. The copyright holder for this preprint (which was not certified by peer review) is the author/funder, who has granted bioRxiv a license to display the preprint in perpetuity. It is made available under aCC-BY-NC 4.0 International license.

temperature, compared to other autumn-sown pulses such as field pea, and a high rate of pod abortion in cool springs (Berger et al., 2005; Lake et al., 2016). These traits determine that severe drought is unlikely before flowering (Chauhan et al., 2017; Lake et al., 2016).

Against this ecological and agronomic background, we modelled the relative risk of drought, heat, and cold stress in the critical period for two contrasting genotypes. We found that drought effect on phenology consistently alleviates the severity of drought during the critical period of yield formation, and that the adaptive value of this trait is higher in more stressful environments, e.g., shallow soil and late sowing. The consistent alleviation of drought stress with hastened flowering relates to the pattern of drought in these environments and cannot be extrapolated to other conditions such as intermittent drought (Jordan and Miller, 1980; Schwinning and Ehleringer, 2001; Tardieu, 2012). Owing to the strong seasonality of rainfall in eastern Australia, crops mostly rely on in-season rainfall in the southern locations of our transect, and rely primarily on stored soil water in the northern locations (Sadras and Rodriguez, 2007); this geographical divide mirrors the early selective pressures for autumn- and springsown crops outlined above. In both cases, slow-growing crops and high availability of soil water (north) or winter rainfall (south) combine to return typically unstressed conditions early in the season, and a characteristic terminal drought with declining water availability during critical reproductive stages in spring as illustrated in Fig. 1a (Chauhan et al., 2017; Lake et al., 2016). The reliability of environmental cues influences the evolution of signalling pathways in plants (Aphalo and Sadras, 2022); a predictable drought pattern over long time scales (millennia) is thus consistent with the selection for hastened flowering in response to drought. The responsive genotype had lower maximum temperature during the critical period, that can further contribute to seed yield, and lower minimum temperature, which could compromise pod set (Berger et al., 2012; Devasirvatham et al., 2012).

\section{Conclusion: biological, agronomic, and modelling implications, and further research}

The combination of experiments in realistic field conditions, Fsт genome scan, and modelling, highlighted the agronomic importance of water deficit effect on chickpea phenology, an overlooked trait. Controlled experiments combining water and thermal regimes, ideally with isogenic lines, are needed to unequivocally assess the agronomic value, i.e., seed yield response, of drought effect on phenology. The genetic variation in our small sample and the relatively high heritability of this trait suggest further research is warranted for breeding applications. Several candidate genes homologous to Arabidopsis thaliana involved in the development of floral and reproductive tissues and stress responses were identified with a putative role in the response of chickpea phenology to drought. Of note, the core genetic regulatory network canalizing the flowering signals to the decision to flower in $A$. thaliana 
partially holds in chickpea (Gursky et al., 2018). Further molecular function experiments are needed to establish their roles for this trait. Irrespective of the actual genes and metabolic pathways, we demonstrated a strong influence of drought on reproductive development that needs to be incorporated in both genetic models (Gursky et al., 2018) and phenotype models that simulate crop phenology, carbon and water dynamics, growth and yield (Chauhan et al., 2019). Models exclusively based on temperature and photoperiod are bound to return biased predictions of phenology, and hence unreliable predictions of crop adaptation to future, drier climates in Australia and elsewhere. 


\section{Acknowledgements}

We thank the Grains Research and Development Corporation for funding (projects UOT1909-002RTX, DAS00140), and Francisco Sadras for expert contribution to data analysis.

\section{Author Contributions}

YL: carried out $\mathrm{F}_{\mathrm{ST}}$ analysis, wrote part of the paper; YSC: modelled phenology and water stress; LL: carried out field experiment, contributed data analysis; JT: carried out statistical analysis; VOS: developed the concept, designed the experiment, analysed data, wrote the manuscript.

\section{Supplementary data}

Supplementary data are available at JXB online.

Table S1. Genetic parameters to model phenological development.

Table S2. ANOVA of thermal time from sowing to flowering, carbon isotope composition, and seed weight.

Table S3. ANOVA of drought effect on phenology.

Table S4. Genes located within $250 \mathrm{~kb}$ of the genomic regions under selection (top $0.1 \% \mathrm{FST}_{\mathrm{ST}}$ ) for DEP Table S5. Summary statistics of frequency distributions of flowering time, water stress index and temperature.

Fig. S1. Comparison of drought effect on phenology calculated with difference- and residual-based approaches.

Fig. S2. WSI deviation from the $y=x$ line as a function of environmental mean WSI.

\section{Data availability}

Dryad, Dataset, https://doi.org/10.5061/dryad.tx95x6b0f

\section{Conflicts of interest.}

The authors declare no conflicts of interest. 
bioRxiv preprint doi: https://doi.org/10.1101/2022.01.26.477940; this version posted January 28,2022 . The copyright holder for this preprint (which was not certified by peer review) is the author/funder, who has granted bioRxiv a license to display the preprint in perpetuity. It is made available under aCC-BY-NC 4.0 International license.

\section{References}

Abbo S, Lev-Yadun S, Galwey N. 2002. Vernalization response of wild chickpea. New Phytologist 154, 695701.

Abbo S, Shtienberg D, Lichtenzveig J, Lev-Yadun S, Gopher A. 2003. The chickpea, summer cropping, and a new model for pulse domestication in the ancient Near East. Quarterly Review of Biology 78, 435-448.

Abbo S, Zezak I, Schwartz E, Lev-Yadun S, Kerem Z, Gopher A. 2008. Wild lentil and chickpea harvest in Israel: bearing on the origins of Near Eastern farming. Journal of Archaeological Science 35, 3172-3177.

Anbazhagan K, Bhatnagar-Mathur P, Sharma KK, Baddam R, Kishor PBK, Vadez V. 2015. Changes in timing of water uptake and phenology favours yield gain in terminal water stressed chickpea AtDREB1A transgenics. Functional Plant Biology 42, 84.

Angus JF, Moncur MW. 1977. Water stress and phenology in wheat. Australian Journal of Agricultural Research 28, 177-181.

Aphalo PJ, Sadras VO. 2022. Explaining Preemptive Acclimation by Linking Information to Plant Phenotype. Journal of Experimental Botany.

Aubert D, Chen LJ, Moon YH, Martin D, Castle LA, Yang CH, Sung ZR. 2001. EMF1, a novel protein involved in the control of shoot architecture and flowering in Arabidopsis. The Plant Cell 13, 1865-1875.

Barr K, Beichman AC, Kalhori P, Rajbhandary J, Bay RA, Ruegg K, Smith TB. 2021. Persistent panmixia despite extreme habitat loss and population decline in the threatened tricolored blackbird (Agelaius tricolor). Evolutionary Applications 14, 674-684.

Berger JD, Ali M, Basu PS, Chaudhary BD, Chaturvedi SK, Deshmukh PS, Dharmaraj PS, Dwivedi SK, Gangadhar GC, Gaur PM, Kumar J, Pannu RK, Siddique KHM, Singh DN, Singh DR, Singh SJ, Turner NC, Yadava HS, Yadav SS. 2006. Genotype by environment studies demonstrate the critical role of phenology in adaptation of chickpea (Cicer arietinum L.) to high and low yielding environments of India. Field Crops Research 98, 230-244.

Berger JD, Buck R, Henzell JM, Turner NC. 2005. Evolution in the genus Cicer - vernalisation response and low temperature pod set in chickpea (Cicer arietinum L.) and its annual wild relatives. Australian Journal of Agricultural Research 56, 1191-1200.

Berger JD, Kumar S, Nayyar H, Street KA, Sandhu JS, Henzell JM, Kaur J, Clarke HC. 2012. Temperaturestratified screening of chickpea (Cicer arietinum L.) genetic resource collections reveals very limited reproductive chilling tolerance compared to its annual wild relatives. Field Crops Research 126, 119-129.

Berger JD, Turner NC, Siddique KHM, Knights EJ, Brinsmead RB, Mock I, Edmondson C, Khan TN. 2004. Genotype by environment studies across Australia reveal the importance of phenology for chickpea (Cicer arietinum L.) improvement. Australian Journal of Agricultural Research 55, 1071-1084.

Booker TR, Yeaman S, Whitlock MC. 2020. Variation in recombination rate affects detection of outliers in genome scans under neutrality. Molecular Ecology 29, 4274-4279.

Calonje M, Sanchez R, Chen LJ, Sung ZR. 2008. EMBRYONIC FLOWER1 participates in Polycomb groupmediated AG gene silencing in Arabidopsis. The Plant Cell 20, 277-291.

Chauhan YS, Allard S, Williams R, Williams B, Mundree S, Chenu K, Rachaputi NC. 2017. Characterisation of chickpea cropping systems in Australia for major abiotic production constraints. Field Crops Research 204, 120-134.

Chauhan YS, Ryan M, Chandra S, Sadras VO. 2019. Accounting for soil moisture improves prediction of flowering time in chickpea and wheat. Scientific Reports 9, 7510.

Chauhan YS, Wright G, Rachaputi N, McCosker K. 2008. Identifying chickpea homoclimes using the APSIM chickpea model. Australian Journal of Agricultural Research 59, 260-269.

Chen YL, Zhang LP, Zhang HY, Chen LG, Yu DQ. 2021. ERF1 delays flowering through direct inhibition of FLOWERING LOCUS T expression in Arabidopsis. Journal of Integrative Plant Biology 63, 1712-1723.

Cheng MC, Liao PM, Kuo WW, Lin TP. 2013. The Arabidopsis ETHYLENE RESPONSE FACTOR1 Regulates Abiotic Stress-Responsive Gene Expression by Binding to Different cis-Acting Elements in Response to Different Stress Signals. Plant Physiology 162, 1566-1582.

Chenu K. 2015. Characterising the crop environment - nature, significance and applications. In: Sadras VO, Calderini DF, eds. Crop physiology: applications for genetic improvement and agronomy. San Diego: Academic Press, 321-348. 
bioRxiv preprint doi: https://doi.org/10.1101/2022.01.26.477940; this version posted January 28,2022 . The copyright holder for this preprint (which was not certified by peer review) is the author/funder, who has granted bioRxiv a license to display the preprint in perpetuity. It is made available under aCC-BY-NC 4.0 International license.

Chenu K, Cooper M, Hammer GL, Mathews KL, Dreccer MF, Chapman SC. 2011. Environment characterization as an aid to wheat improvement: interpreting genotype-environment interactions by modelling water-deficit patterns in North-Eastern Australia. Journal of Experimental Botany 62, 1743-1755.

Coates BS, Hohenstein JD, Giordano R, Donthu RK, Michel AP, Hodgson EW, O'Neal ME. 2020. Genome scan detection of selective sweeps among biotypes of the soybean aphid, Aphis glycines, with differing virulence to resistance to A. glycines (Rag) traits in soybean, Glycine max. Insect Biochemistry and Molecular Biology 124, 103364.

Condon AG, Richards RA, Rebetzke GJ, Farquhar GD. 2002. Improving Intrinsic Water-Use Efficiency and Crop Yield. Crop Science 42, 122.

Cullis BR, Smith AB, Coombes NE. 2006. On the design of early generation variety trials with correlated data. J. Agric. Biol. Env. Stat. 11, 381-393.

Daba K, Deokar A, Banniza S, Warkentin TD, Tar'an B, Francki M. 2016a. QTL mapping of early flowering and resistance to ascochyta blight in chickpea. Genome 59, 413-425.

Daba K, Warkentin TD, Bueckert R, Todd CD, Tar'An B. 2016b. Determination of Photoperiod-Sensitive Phase in Chickpea (Cicer arietinum L.). Frontiers in Plant Science 7.

Devasirvatham V, Tan DKY, Gaur PM, Raju TN, Trethowan RM. 2012. High temperature tolerance in chickpea and its implications for plant improvement. Crop \& Pasture Science 63, 419-428.

DeYoung BJ, Bickle KL, Schrage KJ, Muskett P, Patel K, Clark SE. 2006. The CLAVATA1-related BAM1, BAM2 and BAM3 receptor kinase-like proteins are required for meristem function in Arabidopsis. The Plant Journal 45, 1-16.

DeYoung BJ, Innes RW. 2006. Plant NBS-LRR proteins in pathogen sensing and host defense. Nature Immunology 7, 1243-1249.

Elliott RC, Betzner AS, Huttner E, Oakes MP, Tucker WQJ, Gerentes D, Perez P, Smyth DR. 1996.

AINTEGUMENTA, an APETALA2-like gene of arabidopsis with pleiotropic roles in ovule development and floral organ growth. The Plant Cell 8, 155-168.

Erena MF, Lohraseb I, Munoz-Santa I, Taylor JD, Emebiri LC, Collins NC. 2021. The WtmsDW Locus on Wheat Chromosome 2B Controls Major Natural Variation for Floret Sterility Responses to Heat Stress at Booting Stage. Frontiers in Plant Science 12.

Fang XW, Turner NC, Li FM, Siddique KHM. 2011. An early transient water deficit reduces flower number and pod production but increases seed size in chickpea (Cicer arietinum L.). Crop and Pasture Science 62, 481.

Fumagalli M, Vieira FG, Korneliussen TS, Linderoth T, Huerta-Sanchez E, Albrechtsen A, Nielsen R. 2013. Quantifying population genetic differentiation from next-generation sequencing data. Genetics 195, 979-992. Fumagalli M, Vieira FG, Linderoth T, Nielsen R. 2014. ngsTools: methods for population genetics analyses from next-generation sequencing data. Bioinformatics 30, 1486-1487.

Gaur PM, Samineni S, Tripathi S, Varshney RK, Gowda CLL. 2015. Allelic relationships of flowering time genes in chickpea. Euphytica 203, 295-308.

Golovkin M, Reddy ASN. 2003. A calmodulin-binding protein from Arabidopsis has an essential role in pollen germination. Proceedings of the National Academy of Sciences of the United States of America 100, 1055810563.

Gubert CM, Liljegren SJ. 2014. HAESA and HAESA-LIKE2 activate organ abscission downstream of NEVERSHED and EVERSHED in Arabidopsis flowers. Plant Signaling \& Behavior 9.

Gursky VV, Kozlov KN, Nuzhdin SV, Samsonova MG. 2018. Dynamical Modeling of the Core Gene Network Controlling Flowering Suggests Cumulative Activation From the FLOWERING LOCUS T Gene Homologs in Chickpea. Frontiers in Genetics 9.

Holsinger KE, Weir BS. 2009. Genetics in geographically structured populations: defining, estimating and interpreting F-ST. Nature Reviews Genetics 10, 639-650.

Holzworth DP, Huth NI, deVoil PG, Zurcher EJ, Herrmann NI, McLean G, Chenu K, van Oosterom EJ, Snow V, Murphy C, Moore AD, Brown H, Whish JPM, Verrall S, Fainges J, Bell LW, Peake AS, Poulton PL, Hochman Z, Thorburn PJ, Gaydon DS, Dalgliesh NP, Rodriguez D, Cox H, Chapman S, Doherty A, Teixeira E, Sharp J, Cichota R, Vogeler I, Li FY, Wang E, Hammer GL, Robertson MJ, Dimes JP, Whitbread AM, Hunt J, van Rees H, McClelland T, Carberry PS, Hargreaves JNG, MacLeod N, McDonald C, Harsdorf J, Wedgwood S, Keating BA. 2014. APSIM - Evolution towards a new generation of agricultural systems simulation. Environmental Modelling \& Software 62, 327-350.

Hord CLH, Chen CB, DeYoung BJ, Clark SE, Ma H. 2006. The BAM1/BAM2 receptor-like kinases are important regulators of Arabidopsis early anther development. The Plant Cell 18, 1667-1680. 
bioRxiv preprint doi: https://doi.org/10.1101/2022.01.26.477940; this version posted January $28,2022$. The copyright holder for this preprint (which was not certified by peer review) is the author/funder, who has granted bioRxiv a license to display the preprint in perpetuity. It is made available under aCC-BY-NC 4.0 International license.

Hovav R, Upadhyaya KC, Beharav A, Abbo S. 2003. Major flowering time gene and polygene effects on chickpea seed weight. Plant Breeding 122, 539-541.

Huang HY, Jiang WB, Hu YW, Wu P, Zhu JY, Liang WQ, Wang ZY, Lin WH. 2013. BR Signal Influences Arabidopsis Ovule and Seed Number through Regulating Related Genes Expression by BZR1. Molecular Plant 6, 456-469.

Hulme M. 2020. Climates Multiple: Three Baselines, Two Tolerances, One Normal. Academia Letters. Hunt JR, Lilley JM, Trevaskis B, Flohr BM, Peake A, Fletcher A, Zwart AB, Gobbett D, Kirkegaard JA. 2019. Early sowing systems can boost Australian wheat yields despite recent climate change. Nature Climate Change 9, 244-+. Isbell RF. 1996. The Australian soil classification. Melbourne: CSIRO Publishing. Johansen C, Krishnamurthy L, Saxena NP, Sethi SC. 1994. Genotypic variation in moisture response of chickpea grown under line-source sprinklers in a semiarid tropical environment. Field Crops Research 37, 103112.

Jones H. 1992. Energy balance and evaporation. In: Press CU, ed. Plants and microclimate: a quantitative approach to environmental plant physiology, 106-130.

Jordan KW, Wang S, Lun Y, Gardiner L-J, MacLachlan R, Hucl P, Wiebe K, Wong D, Forrest KL, Sharpe AG, Sidebottom CHD, Hall N, Toomajian C, Close T, Dubcovsky J, Akhunova A, Talbert L, Bansal UK, Bariana HS, Hayden MJ, Pozniak C, Jeddeloh JA, Hall A, Akhunov E, Consortium I. 2015. A haplotype map of allohexaploid wheat reveals distinct patterns of selection on homoeologous genomes. Genome Biology 16. Jordan WR, Miller MR. 1980. Genetic variability in sorghum root system: implications for drought tolerance. In: Turner NC, Kramer PJ, eds. Adaptation of plants to water and high temperature stress. New York: John Wiley and Sons, 383-399.

Kankaanpää T, Vesterinen E, Hardwick B, Schmidt NM, Andersson T, Aspholm PE, Barrio IC, Beckers N, Bêty J, Birkemoe T, Desiervo M, Drotos KHI, Ehrich D, Gilg O, Gilg V, Hein N, Høye TT, Jakobsen KM, Jodouin C, Jorna J, Kozlov MV, Kresse JC, Leandri-Breton DJ, Lecomte N, Loonen M, Marr P, Monckton SK, Olsen M, Otis JA, Pyle M, Roos RE, Raundrup K, Rozhkova D, Sabard B, Sokolov A, Sokolova N, Solecki AM, Urbanowicz C, Villeneuve C, Vyguzova E, Zverev V, Roslin T. 2020. Parasitoids indicate major climate-induced shifts in Arctic communities. Global Change Biology.

Keating BA, Carberry PS, Hammer GL, Probert ME, Robertson MJ, Holzworth D, Huth NI, Hargreaves JNG, Meinke H, Hochman Z, McLean G, Verburg K, Snow V, Dimes JP, Silburn M, Wang E, Brown S, Bristow KL, Asseng S, Chapman S, McCown RL, Freebairn DM, Smith CJ. 2003. An overview of APSIM, a model designed for farming systems simulation. European Journal of Agronomy 18, 267 - 288.

Kim SY, Zhu T, Sung ZR. 2010. Epigenetic Regulation of Gene Programs by EMF1 and EMF2 in Arabidopsis. Plant Physiology 152, 516-528.

Korneliussen TS, Albrechtsen A, Nielsen R. 2014. ANGSD: Analysis of Next Generation Sequencing Data. Bmc Bioinformatics 15.

Krizek BA. 2009. AINTEGUMENTA and AINTEGUMENTA-LIKE6 Act Redundantly to Regulate Arabidopsis Floral Growth and Patterning. Plant Physiology 150, 1916-1929.

Krizek BA, Bantle AT, Heflin JM, Han H, Freese NH, Loraine AE. 2021. AINTEGUMENTA and AINTEGUMENTA-LIKE6 directly regulate floral homeotic, growth, and vascular development genes in young Arabidopsis flowers. Journal of Experimental Botany 72, 5478-5493.

Kumar J, Abbo S. 2001. Genetics of flowering time in chickpea and its bearing on productivity in semiarid environments. Elsevier, 107-138.

Lake L, Chauhan YS, Ojeda JJ, Cossani CM, Thomas D, Hayman PT, Sadras VO. 2021. Modelling phenology to probe for trade-offs between frost and heat risk in lentil and faba bean. European Journal of Agronomy 122, 126154.

Lake L, Chenu K, Sadras VO. 2016. Patterns of water stress and temperature for Australian chickpea production. Crop and Pasture Science 67, 204-215.

Lake L, Sadras V0. 2014. The critical period for yield determination in chickpea (Cicer arietinum L.) Field Crops Research 168, 1-7.

Levine E, Spencer JL, Isard SA, Onstad DW, Gray ME. 2002. Adaptation of the Western Corn Rootworm to Crop Rotation: Evolution of a New Strain in Response to a Management Practice. American Entomologist 48, 94107. 
bioRxiv preprint doi: https://doi.org/10.1101/2022.01.26.477940; this version posted January $28,2022$. The copyright holder for this preprint (which was not certified by peer review) is the author/funder, who has granted bioRxiv a license to display the preprint in perpetuity. It is made available under aCC-BY-NC 4.0 International license.

Li Y, Ruperao P, Batley J, Edwards D, Davidson J, Hobson K, Sutton T. 2017. Genome Analysis Identified Novel Candidate Genes for Ascochyta Blight Resistance in Chickpea Using Whole Genome Re-sequencing Data. Frontiers in Plant Science 8, 359.

Licausi F, Ohme-Takagi M, Perata P. 2013. APETALA/Ethylene Responsive Factor (AP2/ERF) transcription factors: mediators of stress responses and developmental programs. New Phytologist 199, 639-649.

Lichtenzveig J, Bonfil DJ, Zhang H-B, Shtienberg D, Abbo S. 2006. Mapping quantitative trait loci in chickpea associated with time to flowering and resistance to Didymella rabiei the causal agent of Ascochyta blight. Theoretical and Applied Genetics 113, 1357-1369.

Liu D, Chen X, Liu J, Ye J, Guo Z. 2012. The rice ERF transcription factor OsERF922 negatively regulates resistance to Magnaporthe oryzae and salt tolerance. Journal of Experimental Botany 63, 3899-3911. Lizarazo Cl, Isotalo J, Lindfors AV, Stoddard FL. 2017. Progress towards flowering of faba bean (Vicia faba L.) is more than photothermal. Journal of Agronomy and Crop Science 203, 385-396.

Mauney J, Philips LL. 1963. Influence of daylength and night temperature on flowering of Gossypium. Botanical Gazette 124, 278-283.

McDonald GK, Taylor JD, Gong X, Bovill W. 2018. Responses to phosphorus among barley genotypes. Crop \& Pasture Science 69, 574-586.

McMaster GS, Edmunds DA, Wilhelm WW, Nielsen DC, Prasad PVV, Ascough JC. 2011. PhenologyMMS: A program to simulate crop phenological responses to water stress. Computers and Electronics in Agriculture 77, 118-125.

Moffat CS, Ingle RA, Wathugala DL, Saunders NJ, Knight H, Knight MR. 2012. ERF5 and ERF6 Play Redundant Roles as Positive Regulators of JA/Et-Mediated Defense against Botrytis cinerea in Arabidopsis. Plos One 7, e35995.

Muller M, Munne-Bosch S. 2015. Ethylene Response Factors: A Key Regulatory Hub in Hormone and Stress Signaling. Plant Physiology 169, 32-41.

Nielsen R, Williamson S, Kim Y, Hubisz MJ, Clark AG, Bustamante C. 2005. Genomic scans for selective sweeps using SNP data. Genome Research 15, 1566-1575.

Niklas KJ. 1994. Plant allometry: the scaling of form and process. Chicago: University of Chicago Press. Niwa M, Daimon Y, Kurotani K, Higo A, Pruneda-Paz JL, Breton G, Mitsuda N, Kay SA, Ohme-Takagi M, Endo M, Araki T. 2013. BRANCHED1 Interacts with FLOWERING LOCUS T to Repress the Floral Transition of the Axillary Meristems in Arabidopsis. The Plant Cell 25, 1228-1242.

Otegui ME, Cirilo AG, Uhart SA, Andrade FH. 2021. Maize. In: Sadras VO, Calderini DF, eds. Crop Physiology: Case studies in major crops: Academic Press.

Parmesan C. 2006. Ecological and Evolutionary Responses to Recent Climate Change. Annual Review of Ecology, Evolution, and Systematics 37, 637-669.

Patrick JW, Stoddard FL. 2010. Physiology of flowering and grain filling in faba bean. Field Crops Research $115,234-242$.

Pinhasi Van-Oss R, Sherman A, Zhang H-B, Vandemark G, Coyne C, Abbo S. 2016. Vernalization response of domesticated $\mathrm{x}$ wild chickpea progeny is subject to strong genotype by environment interaction. Plant Breeding 135, 102-110.

Rebetzke GJ, Fischer RA, van Herwaarden AF, Bonnett DG, Chenu K, Rattey AR, Fettell NA. 2014. Plot size matters: interference from intergenotypic competition in plant phenotyping studies. Functional Plant Biology 41, 107-118.

Richardson AD, Keenan TF, Migliavacca M, Ryu Y, Sonnentag O, Toomey M. 2013. Climate change, phenology, and phenological control of vegetation feedbacks to the climate system. Agricultural and Forest Meteorology 169, 156-173.

Rodriguez D, Sadras VO. 2007. The limit to wheat water use efficiency in eastern Australia. I. Gradients in the radiation environment and atmospheric demand. Australian Journal of Agricultural Research 58, 287-302.

Sadras VO, Lake L, Li Y, Farquharson EA, Sutton T. 2016. Phenotypic plasticity and its genetic regulation for yield, nitrogen fixation and $\delta 13 \mathrm{C}$ in chickpea crops under varying water regimes. Journal of Experimental Botany 67, 4339-4351.

Sadras V0, Rodriguez D. 2007. The limit to wheat water use efficiency in eastern Australia. II. Influence of rainfall patterns. Australian Journal of Agricultural Research 58, 657-669.

Schwinning S, Ehleringer JR. 2001. Water-use trade-offs and optimal adaptations to pulse-driven arid ecosystems. Journal of Ecology 89, 464-480. 
bioRxiv preprint doi: https://doi.org/10.1101/2022.01.26.477940; this version posted January 28,2022 . The copyright holder for this preprint (which was not certified by peer review) is the author/funder, who has granted bioRxiv a license to display the preprint in perpetuity. It is made available under aCC-BY-NC 4.0 International license.

Singh P. 1991. Influence of water-deficits on phenology, growth and dry-matter allocation in chickpea (Cicer arietinum). Field Crops Research 28, 1-15.

Summerfield RJ, Roberts EH, Erskine W, Ellis RH. 1985. Effects of temperature and photoperiod on flowering in lentils (Lens culinaris Medic.). Annals of Botany 56, 659-671.

Tardieu F. 2012. Any trait or trait-related allele can confer drought tolerance: just design the right drought scenario. Journal of Experimental Botany 63, 25-31.

Thomas, Robertson MJ, Fukai S, Peoples MB. 2004. The effect of timing and severity of water deficit on growth, development, yield accumulation and nitrogen fixation of mungbean. Field Crops Research 86, 67-80. Van Bocxlaer B. 2017. Hierarchical structure of ecological and non-ecological processes of differentiation shaped ongoing gastropod radiation in the Malawi Basin. Proceedings of the Royal Society B: Biological Sciences 284, 20171494.

Wallach D, Palosuo T, Thorburn P, Hochman Z, Andrianasolo F, Asseng S, Basso B, Buis S, Crout N, Dumont B, Ferrise R, Gaiser T, Gayler S, Hiremath S, Hoek S, Horan H, Hoogenboom G, Huang M, Jabloun M, Jansson P-E, Jing Q, Justes E, Kersebaum KC, Launay M, Lewan E, Luo Q, Maestrini B, Moriondo M, Olesen JE, Padovan G, Poyda A, Priesack E, Pullens JWM, Qian B, Schütze N, Shelia V, Souissi A, Specka X, Kumar Srivastava A, Stella T, Streck T, Trombi G, Wallor E, Wang J, Weber TKD, Weihermüller L, de Wit A, Wöhling T, Xiao L, Zhao C, Zhu Y, Seidel SJ. 2021. Multi-model evaluation of phenology prediction for wheat in Australia. Agricultural and Forest Meteorology 298-299, 108289.

Wasserstein RL, Schirm AL, Lazar NA. 2019. Moving to a World Beyond " $p<0.05$ ". The American Statistician 73, 1-19.

Wright S. 1950. Genetical Structure of Populations. Nature 166, 247-249.

Xu X, Liu X, Ge S, Jensen JD, Hu F, Li X, Dong Y, Gutenkunst RN, Fang L, Huang L, Li J, He W, Zhang G, Zheng X, Zhang F, Li Y, Yu C, Kristiansen K, Zhang X, Wang J, Wright M, McCouch S, Nielsen R, Wang J, Wang W. 2012. Resequencing 50 accessions of cultivated and wild rice yields markers for identifying agronomically important genes. Nature Biotechnology 30, 105-U157.

Yoshida N, Yanai Y, Chen LJ, Kato Y, Hiratsuka J, Miwa T, Sung ZR, Takahashi S. 2001. EMBRYONIC FLOWER2, a novel polycomb group protein homolog, mediates shoot development and flowering in Arabidopsis. The Plant Cell 13, 2471-2481.

Yousfi N, Saïdi I, Slama I, Abdelly C. 2015. Phenology, leaf gas exchange, growth and seed yield in Medicago polymorpha L. populations affected by water deficit and subsequent recovery. Flora - Morphology, Distribution, Functional Ecology of Plants 214, 50-60.

Zheng B, Biddulph B, Li D, Kuchel H, Chapman S. 2013. Quantification of the effects of VRN1 and Ppd-D1 to predict spring wheat (Triticum aestivum) heading time across diverse environments. Journal of Experimental Botany $64,3747-3761$. 


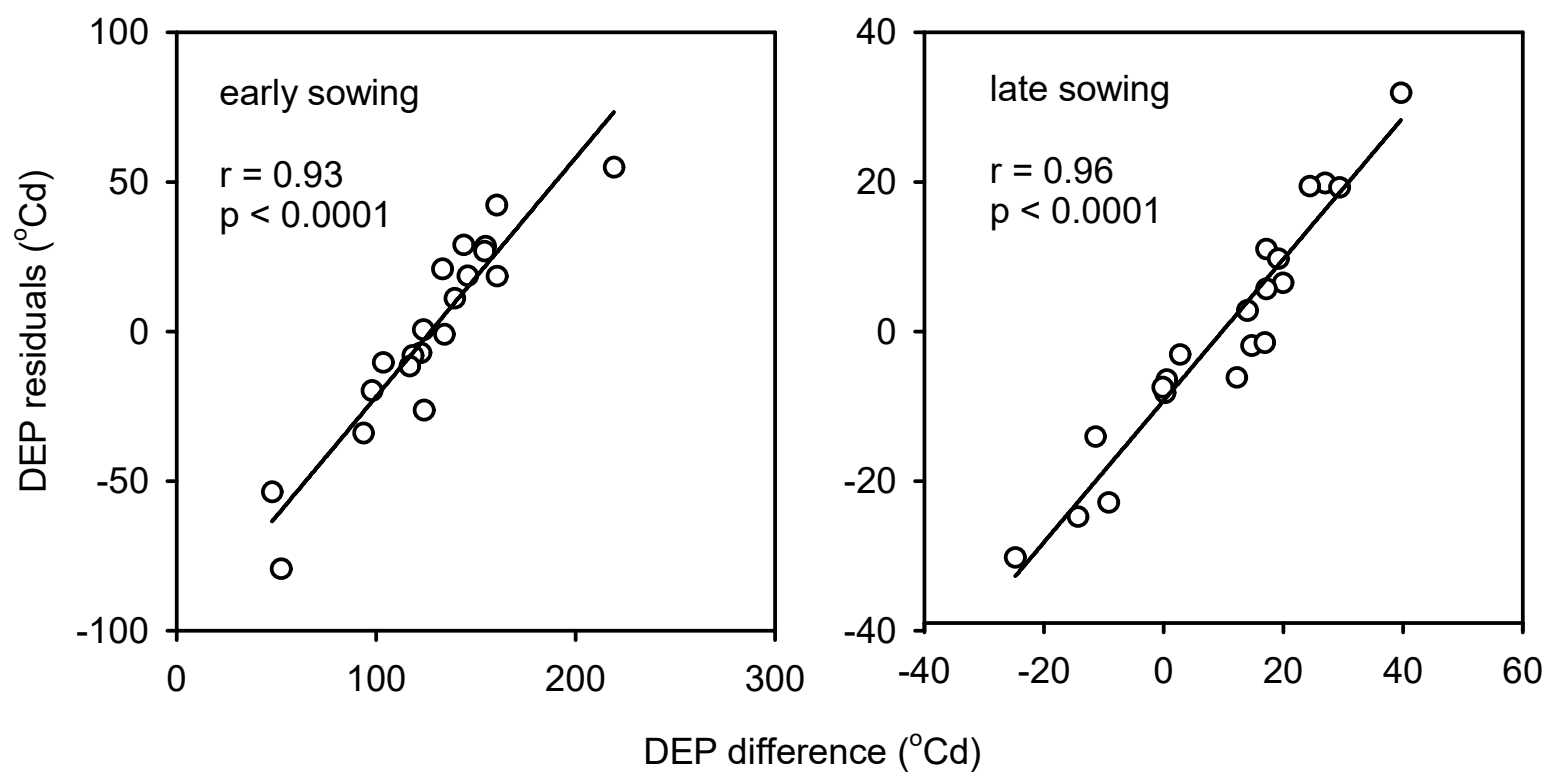

Supplementary Figure 1. Comparison of drought effect on phenology $(D E P)$ calculated with difference- and residual-based approaches. 


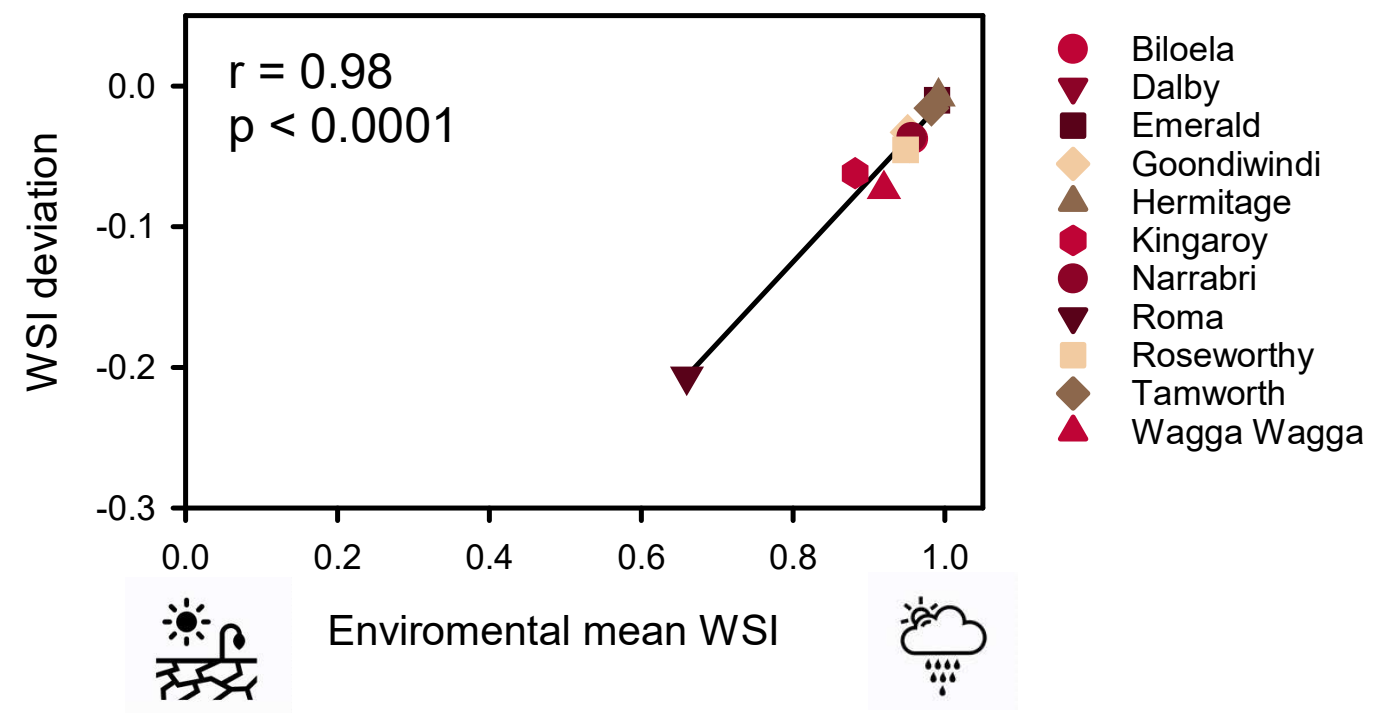

Supplementary Figure 2. WSI deviation from the $y=x$ line in Figure 7a as a function of environmental mean WSI, representing the average water stress index in the critical period for each location, averaged across other factors (65 years, 5 sowing dates, 2 initial soil waters, 2 genotypes). The WSI ranges from 1 (no stress) to 0 (no growth). The line is the least squares regression. 
Supplementary Table 1. Genetic parameters to model phenological development of chickpea.

Parameters are based on measurements and calibrations with PBA Boundary , a locally adapted,

widely used cultivar in commercial crops.

735

\begin{tabular}{llll}
\hline Parameter & Description & Unit & Value or Range \\
\hline tt_emerg_to_endjuv & TT from emergence to end of juvenile phase & ${ }^{\circ} \mathrm{Cd}$ & 650 \\
cum_vernal_days & cumulative vernal days & $\mathrm{d}$ & 0 to 100 \\
est_days_emerg_to_init & Days from emergence to floral initiation & $\mathrm{d}$ & 83 \\
x_pp_endjuv_to_init & Photoperiod & $\mathrm{h}$ & 10.7 to 17.0 \\
y_tt_endjuv_to_init & TT from end juvenile to floral initiation & ${ }^{\circ} \mathrm{Cd}$ & 446 \\
x_pp_init_to_flower & Photoperiod & $\mathrm{h}$ & 1 to 24 \\
y_tt_init_to_flower & TT from initiation to flowering & ${ }^{\circ} \mathrm{Cd}$ & 33 \\
x_pp_flower_to_start_grain & Photoperiod & $\mathrm{h}$ & 1 to 24 \\
y_tt_flower_to_start_grain & TT from flowering to start grain fill & ${ }^{\circ} \mathrm{Cd}$ & 450 \\
x_pp_start_to_end_grain & Photoperiod & $\mathrm{h}$ & 1 to 24 \\
y_tt_start_to_end_grain & TT from start grain fill to end grain fill & ${ }^{\circ} \mathrm{Cd}$ & 690 \\
tt_end_grain_to_maturity & TT from end grain fill to maturity & ${ }^{\circ} \mathrm{Cd}$ & 60
\end{tabular}


Supplementary Table 2. Analysis of variance of thermal time from sowing to flowering, carbon isotope composition $\delta^{13} \mathrm{C}$, and seed weight.

\begin{tabular}{|c|c|c|c|c|c|c|c|}
\hline \multirow[t]{3}{*}{ Source of variation } & \multirow[t]{3}{*}{ Df } & \multicolumn{6}{|c|}{ Thermal time to } \\
\hline & & Wald & & Wald & & Wald & \\
\hline & & statistic & $\operatorname{Pr}($ Chisq) & statistic & $\operatorname{Pr}($ Chisq) & ) statistic & $\operatorname{Pr}($ Chisq) \\
\hline & & & & & $<2.2 \mathrm{E}-$ & & \\
\hline \multirow[t]{2}{*}{ Intercept } & 1 & 577198.6 & $<2.2 \mathrm{E}-16$ & 333960.9 & 16 & 109674.2 & $<2.2 \mathrm{E}-16$ \\
\hline & & & & & $<2.2 \mathrm{E}-$ & & \\
\hline \multirow[t]{2}{*}{ Season } & 1 & 1176.3 & $<2.2 \mathrm{E}-16$ & 76.0 & 16 & 0.6 & 0.43 \\
\hline & & & & & $<2.2 \mathrm{E}-$ & & \\
\hline Sowing time & 1 & 6684.2 & $<2.2 \mathrm{E}-16$ & 459.5 & 16 & 24.1 & $9.08 \mathrm{E}-07$ \\
\hline Water regime & 1 & 228.3 & $<2.2 \mathrm{E}-16$ & 47.6 & 5.19E-12 & 25.4 & 4.70E-07 \\
\hline Genotype & 19 & 3354.7 & $<2.2 \mathrm{E}-16$ & 115.7 & 6.66E-16 & 20406.5 & $<2.2 \mathrm{E}-16$ \\
\hline Season:Sowing time & 1 & 89.8 & $<2.2 \mathrm{E}-16$ & 0.0 & 0.92 & 2.1 & 0.15 \\
\hline Season:Water regime & 1 & 1.7 & 0.19 & 4.2 & 0.04 & 9.3 & 0.002348 \\
\hline Sowing time:Water regime & 1 & 84.3 & $<2.2 \mathrm{E}-16$ & 3.5 & 0.06 & 4.8 & 0.028273 \\
\hline Season:Genotype & 19 & 106.4 & 3.71E-14 & 17.1 & 0.58 & 140.5 & $<2.2 \mathrm{E}-16$ \\
\hline Sowing time:Genotype & 19 & 137.6 & $<2.2 \mathrm{E}-16$ & 15.0 & 0.72 & 30.2 & 0.049 \\
\hline Water regime:Genotype & 19 & 165.2 & $<2.2 \mathrm{E}-16$ & 44.0 & 0.00094 & 77.5 & 4.93E-09 \\
\hline Season:Sowing time:Water regime & 1 & 6.7 & 0.0099 & 0.7 & 0.41 & 2.5 & 0.11 \\
\hline Season:Sowing time:Genotype & 19 & 77.5 & 4.93E-09 & 25.4 & 0.15 & 58.1 & 7.74E-06 \\
\hline Season:Water regime:Genotype & 19 & 48.2 & 0.00024 & 20.5 & 0.37 & 59.8 & 4.12E-06 \\
\hline Sowing time:Water regime:Genotype & 19 & 104.9 & $6.91 \mathrm{E}-14$ & 25.5 & 0.14 & 19.8 & 0.41 \\
\hline \multicolumn{8}{|l|}{ Season:Sowing time:Water } \\
\hline regime:Genotype & 19 & 24.4 & 0.18 & 22.2 & 0.27 & 24.2 & 0.19 \\
\hline Residual (MS) & NA & NA & NA & NA & NA & NA & NA \\
\hline
\end{tabular}


Supplementary Table 3. Analysis of variance of drought effect on phenology.

\begin{tabular}{llll}
\hline Source of variation & Df & Wald statistic & $\operatorname{Pr}($ Chisq) \\
\hline Intercept & 1 & 386.9 & $<2.2 \mathrm{E}-16$ \\
Season & 1 & 72.3 & $<2.2 \mathrm{E}-16$ \\
Sowing date & 1 & 117.0 & $<2.2 \mathrm{E}-16$ \\
Genotype & 19 & 91.4 & $1.87 \mathrm{E}-11$ \\
Season:Sowing date & 1 & 0.2 & 0.63 \\
Season:Genotype & 19 & 43.7 & 0.0010 \\
Sowing date:Genotype & 19 & 88.0 & $7.50 \mathrm{E}-11$ \\
Season:Sowing date:Genotype & 18 & 28.2 & 0.059 \\
Residual (MS) & NA & NA & NA \\
\hline
\end{tabular}


bioRxiv preprint doi: https://doi.org/10.1101/2022.01.26.477940; this version posted January 28, 2022. The copyright holder for this preprint (which was not certified by peer review) is the author/funder, who has granted bioRxiv a license to display the preprint in perpetuity. It is made available under aCC-BY-NC 4.0 International license.

Supplementary Table 4. Genes located within $250 \mathrm{~kb}$ of the genomic regions under selection (top $0.1 \% \mathrm{~F}_{\mathrm{ST}}$ ) for $D E P$. See attached Excel file. 
bioRxiv preprint doi: https://doi. org/10.1101/2022 01 26.477940: this version posted January 28, 2022. The copyright holder for this preprint (which was not certified by peer review) is the author/funder, who has granted bioRxiv a license to display the preprint in perpetuity. It is made available under aCC-BY-NC 4.0 International license.

Supplementary Table 5. Summary statistics of frequency distributions of flowering time, water stress index and temperature for responsive and unresponsive genotypes. Histograms are in Figure 6.

\begin{tabular}{|c|c|c|c|}
\hline Variable & Parameter & Responsive & Unresponsive \\
\hline \multirow{8}{*}{$\begin{array}{l}\text { Time to flowering } \\
\text { (d) }\end{array}$} & Mean & 73 & 89 \\
\hline & Std. Dev. & 11.5 & 17.5 \\
\hline & Minimum & 47 & 55 \\
\hline & Maximum & 110 & 148 \\
\hline & Coef. Var. & 0.16 & 0.20 \\
\hline & Skewness & 0.26 & 0.66 \\
\hline & Kurtosis & -0.18 & -0.02 \\
\hline & Median & 73 & 87 \\
\hline \multirow{8}{*}{$\begin{array}{l}\text { Thermal time to flowering } \\
\left({ }^{\circ} \mathrm{Cd}\right)\end{array}$} & Mean & 878 & 1105 \\
\hline & Std. Dev. & 48.5 & 110.5 \\
\hline & Minimum & 822 & 846 \\
\hline & Maximum & 1051 & 1585 \\
\hline & Coef. Var. & 0.06 & 0.10 \\
\hline & Skewness & 1.29 & 0.43 \\
\hline & Kurtosis & 0.43 & 0.04 \\
\hline & Median & 856 & 1095 \\
\hline \multirow{8}{*}{$\begin{array}{l}\text { Water stress index } \\
\text { (unitless) }\end{array}$} & Mean & 0.978 & 0.927 \\
\hline & Std. Dev. & 0.065 & 0.127 \\
\hline & Minimum & 0.377 & 0.293 \\
\hline & Maximum & 1 & 1 \\
\hline & Coef. Var. & 0.067 & 0.137 \\
\hline & Skewness & -4.27 & -2.23 \\
\hline & Kurtosis & 21.31 & 4.77 \\
\hline & Median & 1 & 0.993 \\
\hline \multirow{8}{*}{$\begin{array}{l}\text { Maximum temperature } \\
\left({ }^{\circ} \mathrm{C}\right)\end{array}$} & Mean & 22.3 & 24.2 \\
\hline & Std. Dev. & 3.2 & 2.9 \\
\hline & Minimum & 14.2 & 16.1 \\
\hline & Maximum & 31.7 & 33.5 \\
\hline & Coef. Var. & 0.14 & 0.12 \\
\hline & Skewness & 0.03 & 0.17 \\
\hline & Kurtosis & -0.43 & -0.30 \\
\hline & Median & 22.3 & 24.1 \\
\hline \multirow{8}{*}{$\begin{array}{l}\text { Minimum temperature } \\
\left({ }^{\circ} \mathrm{C}\right)\end{array}$} & Mean & 7.1 & 8.7 \\
\hline & Std. Dev. & 2.4 & 2.4 \\
\hline & Minimum & -0.1 & 1.5 \\
\hline & Maximum & 16.0 & 16.6 \\
\hline & Coef. Var. & 0.34 & 0.28 \\
\hline & Skewness & 0.22 & 0.16 \\
\hline & Kurtosis & -0.21 & -0.17 \\
\hline & Median & 7.0 & 8.7 \\
\hline \multirow{8}{*}{$\begin{array}{l}\text { Mean temperature } \\
\left({ }^{\circ} \mathrm{C}\right)\end{array}$} & Mean & 14.7 & 16.4 \\
\hline & Std. Dev. & 2.50 & 2.35 \\
\hline & Minimum & 8.9 & 10.8 \\
\hline & Maximum & 22.7 & 24.3 \\
\hline & Coef. Var. & 0.17 & 0.14 \\
\hline & Skewness & 0.28 & 0.34 \\
\hline & Kurtosis & -0.48 & -0.35 \\
\hline & Median & 14.6 & 16.3 \\
\hline
\end{tabular}

